\title{
ABORTO Y JUSTIFICACIÓN ${ }^{*}$
}

\author{
ABORTION AND JUSTIFICATION
}

\section{María Magdalena Ossandón Widow ${ }^{* *}$}

\begin{abstract}
RESUMEN: El artículo analiza las diversas posibilidades de justificación del aborto, particularmente en relación con la eximente de estado de necesidad tal como ha sido consagrada en el nuevo artículo 10 No 11 del Código Penal. Para ello, se estudian las diversas formas que puede asumir el estado de necesidad, que puede ser justificante o exculpante, de carácter defensivo o agresivo. Todas ellas son analizadas en relación con las características particulares del delito de aborto en atención a la regulación constitucional, penal y sanitaria que le es aplicable.
\end{abstract}

Palabras clave: aborto, aborto terapéutico, estado de necesidad defensivo, estado de necesidad agresivo.

ABSTRACT: The article discusses the various posibilities of justification of abortion, particualarly in relation to the state of necessity as it has been enshrined in the new article $10 \mathrm{~N}^{\circ} 11$ of the Penal Code. This purpose is done studying the various ways that the state of necessity can assume, which may be justificatory or exculpatory; defensive or aggressive. All are analyzed in relation to the particular characteristics of the crime of abortion in response to the constitutional, criminal and sanitary regulation that is applicable.

Key words: abortion, therapeutic abortion, defense of necessity, defense of quasi-self-defense.

\section{INTRODUCCIÓN}

Ha sido un tema tradicionalmente discutido el de la posibilidad de que ciertos supuestos de aborto, por las especiales circunstancias en que se desarrollan, estén permitidos, esto es, amparados por una causa de justificación. La justificación podría obtenerse, en principio, por tres caminos: por aplicación de una causa específicamente consagrada al regular el delito de aborto, por aplicación de alguna de las causas generales de justificación que contempla el ordenamiento o, eventualmente, por aplicación de una causa supralegal de justificación.

En otras legislaciones, la primera es la opción que se habría adoptado, en la medida en que el sistema de indicaciones que ellas contemplan es mayoritariamente interpretado como un sistema de causas de justificación por estado de necesidad, consagrado en forma particular para el delito de aborto cuando este se realiza por razones terapéuticas, eugenésicas, éticas, económicas, etc.

\footnotetext{
* Trabajo redactado en el marco del proyecto de investigación Fondecyt No 1090195 "Protección penal de la vida humana: estudio dogmático y crítico".

** Profesora de Derecho penal de la Pontificia Universidad Católica de Valparaíso.

Doctora en Derecho por la Universidad de Navarra.
} 
Nuestra legislación, en cambio, no contempla ninguna disposición particular de esta índole. Antes bien, la única norma que se refería expresamente a una de estas situaciones era el art. 119 del Código Sanitario, que permitía la interrupción del embarazo con fines terapéuticos. Pero fue reemplazado por una disposición que actualmente dispone que no podrá ejecutarse ninguna acción cuyo fin sea provocar un aborto.

El tema vuelve a ser de máximo interés toda vez que acaba de ser modificado nuestro elenco de eximentes de responsabilidad penal para incorporar una nueva causal relativa al estado de necesidad, en el art. 10 No 11 CP. En principio y dada la amplitud de esta disposición, ella consagra una eximente que podría operar bien como causa de justificación, bien como causa de exculpación. En lo que sigue analizaremos el alcance que tiene el nuevo art. 10 No 11 en relación con el delito de aborto, en consonancia con lo que establece el Código Sanitario y las normas constitucionales, a fin de dilucidar si ciertos supuestos de aborto cometidos en situaciones de necesidad pueden reputarse justificados, ya no invocando el ejercicio legítimo de un derecho -como lo ha entendido hasta ahora la doctrina mayoritaria-, sino por aplicación de un estado de necesidad justificante.

Pero antes de entrar al análisis particular de lo que ocurre con el delito de aborto y las situaciones de necesidad, es necesario formular algunas consideraciones previas relativas a lo que significa el juicio de antijuridicidad y su exclusión.

\section{SIGNIFICADO DEL JUICIO DE ANTIJURIDICIDAD}

Afirmar la antijuridicidad de una conducta significa sostener que es contraria a Derecho, cuestión que va más allá de lo puramente ilícito o contrario a la ley ${ }^{1}$. Desde un punto de vista formal, la conducta es antijurídica si contraviene una prohibición o mandato legal; y desde uno material, si en ella plasma una lesión de bienes jurídicos socialmente nociva ${ }^{2}$.

A través de las causas de justificación se trata de legitimar hechos por regla general prohibidos bajo una sanción penal. La concurrencia de una de estas causas implica que la conducta se encuentra permitida o, incluso, exigida, y pasa a ser lícita. Se trata de un juicio de valor, en que la ocurrencia de ciertos supuestos fácticos hace que el Ordenamiento jurídico considere lícita la ejecución de una conducta típica.

La concepción normativa mayoritaria estima que cuando concurre una causa de justificación estamos frente a una autorización que, sin derogar la prohibición general pero superponiéndose a esta, permite la realización de la conducta prohibida en el caso concreto ${ }^{3}$.

En consecuencia, una conducta aparentemente criminal y en principio prohibida, por la concurrencia de una autorización legal expresa ${ }^{4}$-una causa de justificación- deja

\footnotetext{
${ }^{1}$ Cury (2005) p. 353.

${ }^{2}$ Roxin (1997) p. 558.

${ }^{3}$ No entraremos aquí en la discusión sobre la estructura normativa de la justificación, pues sea que se considere que el hecho justificado sigue infringiendo la norma prohibitiva pero amparado por una norma permisiva, sea que se considere que no infringe ninguna norma, en cualquier caso la conducta resulta excepcionalmente justificada, pues de no concurrir la causa de justificación esa conducta estaría prohibida. Sobre las concepciones de la antijuridicidad, Mir Puig (2005) pp. 417-418.

${ }^{4}$ Se entiende que las causas de justificación son preceptos permisivos, autorizaciones expresas de la conducta típica; Muñoz Conde y García Arán (2007) p. 307; Politoff et al. (2011a) p. 209.
} 
de ser antijurídica y puede afirmarse, sencillamente, que es conforme a Derecho ${ }^{5}$, o incluso aprobada por este ${ }^{6}$. Si la antijuridicidad significa una objetiva contrariedad con el Ordenamiento jurídico, la concurrencia de una causa de justificación, en rigor, impide que se origine esa antijuridicidad, aunque se trate de una conducta que afecta gravemente un bien jurídico penalmente protegido, pues es una conducta típica ${ }^{7}$.

Como estas causas de justificación operan en el nivel de la norma primaria, de la prohibición o mandato dirigido a los ciudadanos, no se puede olvidar que ellas "dan pautas de conducta y trazan la frontera entre derecho e injusto" ${ }^{8}$. En otras palabras, al diferenciar el límite entre los comportamientos aprobados por el Derecho y aquellos que no lo están, permiten que la norma opere como modelo orientador de las conductas sociales?.

Estas afirmaciones son de tal entidad que obligan a un examen especialmente riguroso antes de sostener la concurrencia de una causa de justificación. Porque, como acabamos de decir, estaremos frente a una conducta en principio prohibida por su gravedad, porque lesiona o pone en peligro un bien jurídico, y solo de un modo muy excepcional se puede sostener que, a pesar su dañosidad, no resulta contraria a Derecho sino que es aprobada por este. Si la función del Derecho penal es la protección de bienes jurídicos, los supuestos en que se renuncia a la protección penal de tales bienes, en que el legislador abdica de su mandato normativo, deben quedar cuidadosamente delimitados. En otros términos, más normativos: solo de modo excepcional una conducta típicamente relevante no estará, al mismo tiempo, defraudando una expectativa normativa de conducta esencial; solo de modo excepcional ocurrirá que el autor de una conducta socialmente perturbadora no mantenga la competencia por el hecho lesivo, el que deberá ser asumido por terceros o por el propio afectado ${ }^{10}$.

En consecuencia, como dice con sencillez Jаковs, "las causas de justificación son los motivos jurídicos bien fundados para ejecutar un comportamiento en sí prohibido" 11 .

Ahora bien, exigir este carácter excepcional y bien fundado de las causas de justificación no supone hacer una interpretación contraria a la idea de un derecho penal mínimo ${ }^{12}$. Y no lo contradice porque al afirmar que la conducta típica es también antijurídica todavía no se ha pronunciado la última palabra sobre la punibilidad del acto. En realidad, no es extraño que ante una situación aparentemente justificada pero en la que no se configure, en definitiva, una causa de justificación, el autor de la conducta quede de todos modos exento de responsabilidad por carecer de culpabilidad o por otras razones.

La rigurosidad en el juicio sobre una eventual justificación, entonces, viene exigida por las características de este pronunciamiento, las circunstancias en que se emite y, también, por sus consecuencias. En efecto, la diferenciación entre antijuridicidad y culpabili-

\footnotetext{
5 JiméneZ de Asúa (1977) p. 1035.

${ }^{6}$ Fórmula más controvertida, pero usada frecuentemente. Así Muñoz Conde y García Arán (2007) p. 307.

${ }^{7}$ La tipicidad posee un significado valorativo propio, razón por la cual es generalmente rechazada la teoría de los elementos negativos del tipo. Cfr. Mir Puig (2005) p. 164.

${ }^{8}$ Roxin (2007) p. 230.

${ }^{9}$ Laurenzo (1990) p. 320.

${ }^{10}$ Cfr. García Cavero (2008) pp. 467 y 471.

${ }^{11}$ Jаковs (1997) p. 419 (el destacado es nuestro).

12 Algunos hablan de un supuesto "principio pro reo" en la interpretación, que en realidad no existe.
} 
dad tiene significación práctica. Afirmar que una conducta que afecta un bien jurídico es conforme a Derecho -y no meramente exculpada-, tiene como efecto, según el parecer general, que ella no genera ninguna clase de responsabilidad, no solo penal, sino tampoco civil, administrativa, procesal, etc. ${ }^{13}$; que no puede ser impedida o rechazada legítimamente $^{14}$; que debe haber un especial tratamiento para el error sobre la eventual concurrencia de la justificación ${ }^{15}$; y que se cierra la posibilidad de castigar como partícipes a los terceros que intervienen en la conducta justificada. En suma, que una conducta lesiva esté justificada resulta favorable para su autor, pero al mismo tiempo repercute sobre terceros que ven limitada su capacidad de reacción frente a esta, sus posibilidades de indemnización, etc.

Lo dicho hasta aquí corresponde a las situaciones de justificación en un sentido propio o estricto y a sus diferencias con las causas de exculpación.

Sin embargo, hay ciertas situaciones en que la distinción entre causas de justificación y de exculpación parece no ser suficiente, al menos en su sentido y con sus consecuencias tradicionales. Puede que el hecho típico no llegue a estar justificado, pero se presente una situación de conflicto de intereses que haga disminuir el contenido del injusto hasta el punto de hacerlo insuficiente para merecer ser sancionado o, incluso, prohibido penalmente. Son situaciones excepcionales de necesidad, en las que no puede afirmarse que la conducta sea conforme a Derecho, pero en los que parece que el Derecho penal tampoco podría considerarla prohibida, por lo que han llegado a caracterizarse como acciones "no conformes a Derecho pero no prohibidas" 16 . En la actualidad, la discusión sobre estas situaciones límite ha recobrado fuerza a propósito de casos como el del derribo de aviones secuestrados con pasajeros para evitar que se estrellen provocando la muerte de muchas otras personas ${ }^{17}$.

Es conocida la propuesta de GüNTHER de distinguir entre justificación en sentido estricto (exclusión del injusto) y exclusión del injusto penal, esto es, solo del carácter penal del injusto, mientras que la conducta sigue considerándose antijurídica. Según esta visión, habría algunas causas de justificación que excluyen el injusto sin más, para todos los campos del Derecho, y otras causas que eliminan solo el injusto jurídico-penalmente relevante ${ }^{18}$. Otras soluciones pasan por considerar que estaríamos ante conductas "jurídicamente neutrales" o "indiferentes"19; o, incluso, que son situaciones que se configuran como espa-

\footnotetext{
${ }^{13}$ Afirmación muy discutible, pues en ocasiones la justificación solo impone al tercero afectado un deber de tolerar el salvamento pero no el de soportar el costo económico que ello implica, García Cavero (2008) p. 478. Serían problemas independientes, pues "la cuestión aquí radica en saber quién ha de soportar económicamente un daño cuando la ley lo autoriza, no si esta lo autoriza" Politoff et al. (2011a) p. 213.

${ }^{14}$ Dicho en otros términos, generaría deberes de tolerancia o, al menos, la obligación de no repeler la intervención justificada.

${ }^{15}$ Diferencia que se explica en su fundamento: "Quien supone una situación de justificación quiere hacer algo que también coincide con el Derecho en caso de una apreciación objetiva; esto merece en todo caso una pena por imprudencia. Por el contrario, quien supone una situación de exculpación, sabe que actúa antijurídicamente y hace esto también dolosamente. Luego, ha tenido suficientes motivos para apartarse de su conducta [...] esto no es motivo para liberarlo sin más de una pena por dolo", Roxin (2007) p. 240.

${ }^{16}$ Binding, Handbuch des Strafrechts (1881), 1995, p. 765, cit. por Roвles (2010) p. 465.

${ }^{17}$ Vid., por ejemplo, Robles (2010), Martínez (2010), Hirsch (2008).

${ }^{18}$ GÜnther (1995) pp. 48-49. Críticos, entre otros, Díez (2011) y Laurenzo (1990) p. 289 y ss.

${ }^{19}$ Gimbernat ([1974] 1990) pp. 228 y 230, de este modo concluye que el estado de necesidad siempre opera como justificante (teoría unitaria sobre el estado de necesidad).
} 
cios libres de Derecho, en los que el legislador retira sus normas, renuncia a una valoración, dejando que el particular decida cómo comportarse ${ }^{20}$.

No entraremos en la discusión sobre el contenido preciso ni la ubicación sistemática de estas situaciones, cuestión que excede ampliamente las posibilidades de este estudio y respecto de la cual existen soluciones muy diversas (exclusión de la antijuridicidad, de la culpabilidad, de categorías intermedias, de la pena, etc. $)^{21}$. Pero sí queremos destacar que aunque puedan llegar a estimarse causas de exclusión del injusto penal, en ellas subsisten diferencias importantes con las conductas justificadas, que son expresamente permitidas y positivamente valoradas por el Ordenamiento jurídico 22 . "Una conducta está justificada cuando la colisión de dos bienes jurídicos se soluciona de manera legal, permitiendo la intervención" ${ }^{3}$. Es decir, goza de un permiso fuerte, que incide en la norma de conducta de tal modo que el comportamiento no constituye infracción contra ninguna norma jurídica ${ }^{24}$, y que genera deberes de tolerancia para los que pueden verse afectados por la conducta justificada. Como apunta MoLina Fernández, "esgrimir derechos o ejercer deberes, cuando ello entrañe la lesión o peligro para bienes penalmente protegidos, es actuar justificadamente" 25 . Nada de eso sucede en estas situaciones de eventual exclusión del injusto penal, las que, si es que llegan a considerarse penalmente permitidas, no lo serían más que en un sentido débil, que no genera deberes de tolerancia, por lo que es posible la defensa frente a la conducta del necesitado.

En lo que sigue estudiaremos la posibilidad de justificación del aborto en sentido estricto, es decir, atendiendo a si resulta aplicable en este delito alguna causa de justificación que permita la conducta y, en particular, si se puede ver justificado en razón de un estado de necesidad.

En este análisis sobre la eventual concurrencia de una causa de justificación, más allá del fundamento que se le asigne en general a estas causas -en torno al cual existen posiciones monistas, que identifican un fundamento único y común a todas, o pluralistas, que establecen diversos fundamentos en torno a los cuales se agrupan las variadas causas de justificación-, interesa sobre todo el conflicto particular que se resuelve al afirmar la justificación o

20 Teoría defendida especialmente por Arthur Kaufmann; es criticada, entre muchos, por GuZMÁn Dalbora (2003) y LaURenzo (1990) pp. 172 y ss.

${ }^{21}$ En esta discusión ha primado la preocupación por el problema sistemático sobre la relativa al fundamento y límites de la exención de responsabilidad, cfr. Silva SÁnchez (1999) p. 165. En todo caso, estos planteamientos no han encontrado demasiada aceptación, y se sigue defendiendo una distinción clara entre causas de justificación y de inculpabilidad como dogmáticamente fructífera, por lo que no debería ser difuminada a través de equiparaciones simplificantes y nuevas formas intermedias, según Roxin (2007) p. 258. De acuerdo, SANZ (2000) p. 77.

22 Se trata de diversos niveles axiológicos, como advierte Perron (1998) p. 140. El mismo Günther (1995) pp. 53-59 hace una clasificación de las causas que él considera de justificación, en orden de intensidad, que demuestra la diversa valoración que existe entre las conductas exigidas (por deberes jurídicos) o expresamente permitidas (por ejercicio de derechos conferidos por el ordenamiento) y estas otras causas de exclusión únicamente del injusto penal.

${ }^{23}$ Roxin (2007) p. 258.

${ }^{24}$ Es importante distinguir si la impunidad de una conducta se debe a que no infringe norma jurídica alguna o si estamos solo ante una renuncia a la sanción penal, Perron (1995) p. 85 y ss.

${ }^{25}$ Molina (2008) p. 30. 
no de una determinada conducta. Ese conflicto, que da origen a cada justificante y que esta procura resolver, debe analizarse y sopesarse cuidadosamente antes de decidir el punto.

\section{POSIBILIDADES DE JUSTIFICACIÓN DEL ABORTO. ESTADO DE LA CUESTIÓN}

En principio, cualquier conducta típica podría estar, según las circunstancias del caso, justificada. Pero en ciertos delitos puede descartarse a priori la concurrencia de posibles causas de justificación cuando resultan incompatibles con el tipo en cuestión.

El delito de aborto es uno de aquellos casos en que la licitud resulta especialmente controvertida y para comprobarlo analizaremos la posibilidad de concurrencia de las diversas causas de justificación. En general, las consideraciones estarán especialmente enfocadas hacia los casos en que está en peligro la vida o la salud de la madre, es decir, supuestos de aborto terapéutico, sin perjuicio de que lo que se diga sea usualmente extrapolable a otros supuestos.

\section{a. Consentimiento}

Se puede definir como la aceptación o autorización otorgada de forma libre y consciente por el titular de un bien jurídico disponible para la ejecución de una conducta típica que lesiona o pone en peligro dicho bien.

Respecto del aborto no es procedente por dos razones. En primer lugar porque el bien jurídico protegido -la vida del feto- no es disponible, ni siquiera para su titular. Y segundo, porque el titular del dicho bien -el feto- no está en condiciones de prestar su consentimiento; y aun cuando, en ocasiones, las personas que ejercen legítimamente la representación del titular del bien jurídico pueden prestar el consentimiento en su nombre, esto último no es admisible respecto de bienes jurídicos personalísimos, como la vida.

Que el consentimiento de la mujer embarazada no tiene relevancia queda demostrado, por lo demás, en tanto se tipifican como delito supuestos de aborto consentido (artículos 342 No 3 y $344 \mathrm{CP})$.

\section{b. LEGÍTIMA DEFENSA}

Obra en legítima defensa quien ejecuta una acción típica, racionalmente necesaria, para repeler o impedir una agresión ilegítima, no suficientemente provocada por él y dirigida en contra de su persona o derechos, o de los de un tercero.

La base de la legítima defensa es la existencia de una agresión, frente a la cual surge una reacción defensiva. $Y$ en tanto dicha agresión es ilegítima, el interés legítimo de defensa resulta preponderante frente al interés -ilegítimo- del agresor.

En relación con esta agresión, hay acuerdo en que ella es ante todo una actividad, una conducta de un ser humano, e incluso algunos exigen voluntad de ataque o dirección de la voluntad a producir una lesión ${ }^{26}$. Se reconoce, en todo caso, que la agresión puede provenir de un inimputable, pues estos actúan y su conducta puede ser ilegítima, aunque en estos supuestos "el interés en el prevalecimiento del Derecho es sustancialmente menor

${ }^{26}$ Con referencias Rivacoba (1995) p. 128. 
que en el caso normal" 27 , lo que supone limitar la defensa a lo imprescindible para la protección del agredido.

Es patente que el feto es incapaz de una agresión en estos términos ${ }^{28}$. Por lo demás, aunque fuera una agresión tampoco podría considerarse ilegítima o contraria a Derecho ${ }^{29}$, características que solo pueden predicarse de una conducta humana.

Y por último, en los casos de aborto terapéutico la posibilidad de invocar una legítima defensa estará también impedida cuando el riesgo frente al que se reacciona no sea de la actualidad o inminencia que esta causa de justificación requiere.

\section{c. Estado de NECESIDAD JUSTIFICANTE}

Por estado de necesidad en sentido amplio se entiende cualquier situación en la que se sacrifica un bien jurídico para salvar otro que se encuentra en peligro. De conformidad con la teoría de la diferenciación, es reputado justificante solo cuando implique evitar la lesión de un bien más valioso que el sacrificado.

Tradicionalmente nuestra legislación fue muy restrictiva al consagrar esta causa de justificación, admitiéndola únicamente cuando el bien jurídico sacrificado era la propiedad ajena (art. 10 No 7) o la inviolabilidad de la morada (art. 145). El sacrificio de otros bienes en una situación de necesidad no daba lugar a un estado de necesidad justificante, aunque podía configurar una causa de inculpabilidad por no exigibilidad de otra conducta.

En ese contexto el delito de aborto quedaba, obviamente, fuera de su ámbito de aplicación.

Pero esta situación ha cambiado radicalmente con la reciente modificación del art. 10 No $11 \mathrm{CP}$, que ahora describe el estado de necesidad en términos mucho más amplios. Dado que ese es el objeto central de este artículo, abordaremos el tema con detalle más adelante.

\section{d. EJERCICIO LEGÍtimo DE UN DERECHO}

Obra de modo justificado quien ejercita un derecho que le ha sido conferido por el Ordenamiento jurídico.

No es aplicable en relación con el delito de aborto pues no existe ninguna norma que confiera, de modo expreso o tácito, la facultad de abortar. Nuestro ordenamiento jurídico no reconoce, sin más, un derecho a abortar. Si es que ello fuera posible lo sería solo en el contexto de la actividad médica, por lo que la cuestión se traslada a la siguiente causa de justificación.

\section{e. EJERCICIO LEGÍtTIMO DE UNA AUTORIDAD, OFICIO O CARGO}

Aunque esta causa de justificación parece una especificación de la anterior, no debe identificarse con ella. En el ejercicio de una autoridad, oficio o cargo, más que de facultades

27 Roxin (1997) pp. 637-638, entiende que la protección frente al injusto, cuando el agresor no es culpable, debe mantenerse en los límites que exige la consideración social.

${ }^{28}$ Etcheberry (1998) p. 106 considera la "dificultad de calificar de agresión la simple existencia y desarrollo del feto, que no llegan a constituir siquiera acción en el sentido penal", y GARRIDo (2007) p. 118, n. 225, entiende que "la agresión supone el ataque de una persona, y el nasciturus no ataca y tampoco es persona".

${ }^{29}$ En ese sentido Vivanco (2002) p. 169. 
o derechos, cabe hablar de deberes, pues no ejercerlos puede conllevar una sanción. Quien asume un cargo o una labor que implique autoridad, y quien se compromete a desarrollar las tareas propias de un oficio, toma sobre sí determinadas obligaciones, y en ese contexto puede incurrir en una conducta típica pero justificada ${ }^{30}$.

Otra diferencia, además de la anterior, es que cuando se trata del ejercicio de un derecho, los derechos de que se trata tienen su fuente en el Ordenamiento jurídico, que además fija las condiciones bajo las cuales resulta legítimo su ejercicio. En el ejercicio de una autoridad, oficio o cargo -salvo si es una función pública regulada por la ley- la fuente de la actuación y las condiciones para su legitimidad han de buscarse en los términos de la relación contractual que le sirve de base y en la regulación de la forma en que han de desarrollarse determinadas actividades profesionales o prestarse algunos servicios, regulación que puede ser consuetudinaria e informal.

Precisamente, antes de que se regulara el aborto terapéutico en el Código Sanitario en el año 1931, se apelaba a la lex artis médica no escrita para configurar en ese evento la justificante de ejercicio legítimo de un oficio, contemplada de modo genérico en el art. 10 No $10 \mathrm{CP}^{31}$.

Una vez recogido en la legislación sanitaria, aunque mayoritariamente se concebía como una hipótesis de estado de necesidad ${ }^{32}$, algunos lo consideraban parte del ejercicio legítimo de la profesión de médico ${ }^{33}$. Esto suponía varias consecuencias íntimamente vinculadas entre sí. Por una parte, que no quedaba sometido al estricto juicio de ponderación propio del estado de necesidad justificante; así, a medida que los progresos de la medicina permitieron controlar y reducir las situaciones extremas de peligro inminente de muerte para la embarazada, las que se fueron haciendo cada vez más extraordinarias, el art. 119 del Código Sanitario podía igual invocarse en supuestos de peligro futuro para la vida o, incluso, para la salud de la mujer ${ }^{34}$. Por otra parte, en tanto ejercicio legítimo de una profesión la causal solo podía ser invocada por un médico ${ }^{35}$ quien debía someterse a las exigencias de la lex artis médica ${ }^{36}$. Para quienes defendían esta posición, en todo caso, cuando la situa-

${ }^{30}$ Rodríguez (2010) IX, p. 11.

31 Así lo reconocen Politoff et al. (2006) p. 245.

32 Cousiño (1979) pp. 353, 425-430; Labatut (2007) p. 128 y, particularmente riguroso, EtcheberRy (1965) pp. 101-102, referido al art. 226 del DFL 2.226 de 1931, у Eтcheberry (1976) pp. 73-76, referido al art. 119 del DFL 725 de 1967.

${ }^{33}$ En este sentido Politoff et al. (2006) p. 249.

${ }^{34}$ En este sentido Manríquez (1963) pp. 43-44; Parada (1963) p. 76, y Politoff et al. (2006) p. 245. Lo restringían solo al peligro para la vida, Etcheberry (1965) pp. 101-102 y Fernández (1921) p. 28.

35 Esto último era discutido, pues aunque la disposición original del Código sanitario (art. 226) exigía que la operación fuese efectuada por un médico, la supresión del inciso que contenía esa mención podía usarse como argumento para extender la justificante a otras personas que no fueren médicos. Politoff et al. (2006) pp. 248249 explican los argumentos para seguir restringiendo su aplicación a los médicos: que el sistema jurídico solo permite a estos profesionales la actividad terapéutica, y cuando la autoriza a otros profesionales (como las matronas) lo hace en términos restringidos; que la ampliación de la justificante más allá de las exigencias del estado de necesidad -no se requiere un mal real o inminente sino solo un peligro-, opera sobre la base de la experiencia médica utilizada con arreglo a la lex artis; y que la finalidad terapéutica supone el conocimiento sobre el carácter indispensable de la intervención abortiva, única forma de evitar la charlatanería, el curanderismo y la profesionalización en la práctica de abortos.

${ }^{36}$ Cuestión relevante para pronunciarse sobre la necesidad del consentimiento de la gestante, real o presunto, 
ción quedaba fuera de los márgenes establecidos por el art. 119 del Código Sanitario, de todos modos la conducta podía ser impune invocando un estado de necesidad supralegal o por inexigibilidad de otra conducta ${ }^{37}$.

Por Ley No 18.826 de 1989 se modificó ese artículo 119 estableciendo su actual redacción: no podrá ejecutarse ninguna acción cuyo fin sea provocar un aborto.

Pese a lo anterior, gran parte de la doctrina persiste en la tesis de que el aborto terapéutico se incluye dentro del ejercicio legítimo de una profesión, considerado como causa de justificación o, más aún, de atipicidad ${ }^{38}$. Su aplicación supondría que se trate de un médico que actúe cumpliendo los requisitos que legitiman una intervención médico quirúrgica, es decir, con el consentimiento del paciente, con una finalidad terapéutica, y cumpliendo todas las exigencias de la lex artis; siempre que exista una causa proporcional que permita atentar contra un bien jurídico protegido por la Constitución.

ETCHEBERRY apoya su interpretación en que la vida de la madre es considerada por la ley como más valiosa que la del feto y que una actitud meramente pasiva del médico parece incompatible con la posición de garante que ha asumido con respecto a la mujer que es su paciente. Además, destaca que la propia ley por la que se derogó la disposición que consagraba el aborto terapéutico reconoce que, aunque sean excepcionales, sigue habiendo casos en que la vida de la madre pueda verse amenazada por la prosecución del embarazo, y que tal situaciones deberán resolverse conforme a las reglas generales. Como esas reglas no permiten invocar otra causal de justificación que no sea el ejercicio legítimo de un derecho u oficio en ese caso, "si esa causal no es aplicable a los médicos, ninguna otra lo será y la excepción reconocida por el preámbulo de la Ley 18.826 no se daría jamás”39.

Además de compartir el argumento de Etcheberry, en el sentido de que el art. 10 No 10 sobre ejercicio legítimo de un derecho constituye la "regla general" del Código Penal para resolver el conflicto del aborto terapéutico, Politoff, Matus y Ramírez agregan el antecedente de una declaración del Departamento de Ética del Colegio Médico que admitiría la práctica del aborto terapéutico ${ }^{40}$.

Bullemore y Mackinnon, en la misma línea, aluden a un concepto amplio de lex artis referido no solo a reglas y procedimientos médicos, sino también a principios. Entre estos interesa especialmente el de la relación médico-paciente como principio rector, que permitiría prescindir del contenido del art. 119 CS para garantizar la vida o salud de la madre ${ }^{41}$.

Usando un criterio más radical, Sanhueza Romero restringe el significado del art. 119 CS atribuyéndole solo la función de haber derogado la presunción de legitimidad de

como reconocimiento de la libertad del paciente frente a las razones terapéuticas, y para determinar lo que se entendía por finalidad terapéutica. Politoff et al. (2006) pp. 250-253.

37 Politoff et al. (2006) p. 255. Con posterioridad a la reforma del CS, también, Politoff et al. (2011b) p. 98.

38 Bullemore y Mackinnon (2007) pp. 50-52 y Garrido (2007) p. 118, n. 225 hablan de atipicidad o subsidiariamente, justificación. Por esta última opción se inclinan Etcheberry (1998) pp. 105-109; Oxman (2004) p. 244; Politoff et al. (2011b) pp. 96-97, y Sanhueza (1990) pp. 32-33.

${ }^{39}$ Etcheberry (1998) p. 108.

${ }^{40}$ Politoff et al. (2011b) p. 96.

${ }^{41}$ Bullemore y Mackinnon (2007) pp. 50-52. 
la conducta abortiva terapéutica, antes permitida expresamente. Fuera de eso, no sería más que una reafirmación del indicio de antijuridicidad del tipo de aborto, una mera reiteración de la prohibición que contiene el Código Penal, dejando al aborto terapéutico en la misma situación que existía a la época de dictación de ese cuerpo legal ${ }^{42}$.

No pueden compartirse estas posturas, por varias razones.

Como bien clarifica Bascuñán Rodríguez, el artículo 10 No 10 no contiene una norma justificante en sí misma, sino que constituye una metarregla, esto es, una disposición que ordena dar prioridad a las normas del ordenamiento jurídico que autorizan a realizar las acciones $\mathrm{u}$ omisiones típicas por sobre las normas punitivas ${ }^{43}$. En sentido similar, Molina Fernández describe el ejercicio legítimo de un derecho como una regla vacía de contenido justificante, pero que permite la incorporación al Derecho penal de las circunstancias específicas de justificación diseminadas por el ordenamiento, constituyendo un "generador universal de leyes penales en blanco en el ámbito de la justificación" 44 . En consecuencia, para poder aplicar esta causa de justificación es necesario identificar otra norma, además de la del art. 10 No 10 , que autorice a realizar el comportamiento ${ }^{45}$. No basta una referencia genérica, porque se trata de legitimar excepcionalmente una conducta que por regla general está prohibida, por lo que tanto la existencia del derecho como las condiciones para su legítimo ejercicio deben provenir de una norma jurídica, cualquiera sea la fuente de la que ella emane (ley formal, costumbre, contrato, etc. $)^{46}$.

Tratándose de la actividad de un profesional de la medicina esa norma debería encontrarse en los diversos cuerpos normativos que la regulan o en las demás fuentes que integran la lex artis. Sin embargo, no existe una disposición que autorice el aborto por razones terapéuticas, sino más bien lo contrario: se prohíbe expresamente cualquier acción que tenga por fin provocar un aborto, permitiéndose únicamente las intervenciones curativas que puedan producir un aborto de modo indirecto. Pretender que los médicos tienen derecho a provocar directamente un aborto en razón del legítimo ejercicio de su profesión significa desconocer, lisa y llanamente, lo dispuesto en el art. $119 \mathrm{CS}^{47}$. No se pretende, con

\footnotetext{
42 Sanhueza (1990) pp. 32-33.

43 Bascuñán (2004a) p. 165.

${ }^{44}$ Molina (2008) pp. 26 y 31.

${ }^{45}$ La causa de justificación del ejercicio legítimo de un derecho, autoridad, oficio o cargo es, en consecuencia, limitada. Eso explica que existan otras causas de justificación, pues de lo contrario serían innecesarias todas las demás, y que se reconozcan causas de justificación supralegales. Esto último, sin embargo, resulta muy discutido. Sobre la necesidad de causas supralegales, RivacoBa (1995) p. 41-43; sobre el ejercicio de un derecho como cláusula de cierre del sistema, Carbonell (1982) p. 128. Paulatinamente, sin embargo, estas teorías han sido superadas por un amplio reconocimiento del estado de necesidad justificante, que operaría entonces como dicha cláusula de cierre del sistema de justificación. Cfr. Molina (2008) pp. 31-33.

46 Rivacoba (1995) pp. 47 y 78.

${ }^{47}$ Horvitz y Soto Piñeiro (2007) p. 85, n. 21 entienden que "si pese a la historia fidedigna de su establecimiento, se considera que el art. 119 del CS, en su actual redacción, no es obstáculo para la admisión del denominado aborto terapéutico, entonces la reforma de 1989 habría carecido de todo sentido o propósito, pues el estatus normativo antes y después de la reforma sería exactamente el mismo, lo que parece un evidente contrasentido. Las leyes, por un mínimo de deferencia con el legislador, deben interpretarse siempre en el sentido que produzcan algún efecto". Y agregan que aun cuando la eximente del art. 10 No 10 CP "no fuera (como es) una metarregla y supuesto que su contenido previo hubiera estado definido con independencia del art. 119 (en su antigua redacción) y en términos antinómicos con el actual contenido del art. 119 del CS., tanto por espe-
} 
esto, atribuir una importancia exagerada a esta disposición ${ }^{48}$, sino reconocer que tiene efecto normativo y que constituye parte de la regulación legal de la lex artis médica, que "tanto por jerarquía, como por especialidad, prima sobre las normas reglamentarias o puramente éticas de signo contrario que, de existir, pudieran oponérsele" 49.

Por lo demás, tampoco se trata de enfrentar lo estipulado en el art. 119 CS con otras disposiciones contrapuestas, pues no existe una regulación permisiva en esta materia. La normativa propia del Colegio Médico ha experimentado una evolución similar a la del Código Sanitario. En efecto, la autorización que contemplaba el antiguo Código de Ética de 1983 para realizar un aborto como medida terapéutica ha sido derogada ${ }^{50}$; a partir de la reforma de 2004, confirmada en la versión de 2008, lo que se estipula es lo siguiente:

Art. 8. El respeto de la vida humana desde su inicio y hasta su término constituye el fundamento básico del ejercicio profesional médico.

Toda intervención médica realizada durante los nueve meses de gestación, deberá velar siempre por el mejor interés de la madre y del hijo.

Art. 9. El médico no podrá realizar acciones cuyo objetivo directo sea poner fin a la vida de un paciente bajo consideración alguna.

De este modo, puede advertirse que en su normativa profesional los médicos prohíben tanto el aborto como el homicidio que se realicen con el objetivo directo de poner fin a la vida del feto o del ya nacido, mientras que quedarían fuera de esa prohibición las conductas que lleven a ese mismo resultado de modo no intencional, sino como consecuencia

cialidad, como por temporalidad debería primar este último al momento de asignar un contenido a la lex artis, luego a la eximente, en relación al aborto".

${ }^{48}$ Como denuncian Bullemore y Mackinnon (2007) pp. 50-52.

${ }^{49}$ Horvitz y Soto Piñeıro (2007) p. 88, n. 28, entendiendo que el art. 119 del CS constituye un antecedente insoslayable al momento de precisar el contenido de la lex artis en este ámbito. En igual sentido, Bascuñán (2004a) p. 164. Como única forma de aceptar la justificación del aborto terapéutico dentro del marco del ejercicio legítimo de la profesión, estos autores sostienen la inconstitucionalidad de dicha norma, porque atentaría contra el principio de igualdad ante la ley, en la medida en que restringe la posibilidad de aplicación del estado de necesidad defensivo justificante respecto del feto, el que sí sería procedente respecto de cualquier persona nacida. Sobre el particular volveremos al estudiar dicha causa de justificación.

${ }^{50}$ Tampoco tendría valor la declaración a que se referían Politoff et al. (2011b) p. 96. Ella corresponde a la del Departamento de Ética del Consejo General del Colegio Médico de Chile: Aborto: Interrupción del Embarazo como Medida Terapéutica en Casos de Gestantes con Riesgo de Muerte al Continuar la Gravidez, de febrero del año 2003. Pero es obvio que una declaración de esta clase no puede ser considerada por sobre disposiciones expresas. Además puede entenderse tácitamente derogada por la posterior reforma del Código de Ética. Pero más relevante que lo anterior es que ni siquiera resultaba una autorización del aborto terapéutico más allá de lo que establece el propio art. 119 CS. En efecto, luego de reconocer que aún persisten algunas indicaciones en que, lamentablemente, no queda otra solución que proceder con la interrupción de la gestación, en ella se afirma que "en estos casos, la intervención -cuya intención es obviamente preservar la vida de la madre- está orientada, al menos, por los principios de beneficencia, de no maleficencia y el respeto a la autonomía de la madre. Si se vulneran los derechos del hijo que está en el seno materno, ello ocurrirá como producto de un acto proporcionado, que lo afecta indirectamente, por cuanto no fue realizado con la intención primaria de dañarlo sino que procurando un mayor bien. Esta acción se denomina de doble efecto y éticamente se valida por el sentido de lo intentado y no de lo que escapa a la intención". 
probable o segura de un tratamiento o intervención curativas, realizadas con estricto apego a la lex artis.

Las disposiciones comentadas impiden, a su vez, invocar el principio de la relación médico-paciente como criterio normativo rector que obligue al médico a salvar a la madre por medio de la muerte del feto, pues eso supondría invocarlo -en contra de otras disposiciones de la propia lex artis-, como si el único paciente fuera la madre, en circunstancias que tanto ella como el niño por nacer son merecedores de la preocupación del médico. Por lo tanto, ese mismo principio rector de la medicina es el que impide extender su ejercicio legítimo a conductas directamente encaminadas a dar muerte al feto.

Por último, en relación con el argumento según el cual si no se acepta la concurrencia de esta causa de justificación la excepción reconocida por el preámbulo de la Ley No 18.826 no se daría jamás, tampoco es efectivo. Todo lo que dicho preámbulo establece es que las situaciones excepcionales de aborto terapéutico habrán de resolverse de conformidad con las reglas generales. Y, según veremos más adelante, aun cuando se niegue la justificación, bien puede resolverse esta situación por medio de las causales de inexigibilidad de otra conducta.

En definitiva, en el marco de la actuación médica son lícitas las conductas terapéuticas que indirectamente pueden derivar en un aborto. Pero resulta improcedente pretender amparar un aborto intencional realizado por razones terapéuticas respecto de la madre en el ejercicio legítimo de la profesión médica, pues su propia regulación lo impide.

Más precisamente, entendemos que la función de dicha regulación es determinar los límites de lo que se considera riesgo permitido y, por ende, objetivamente atípico ${ }^{51}$. En ese sentido, "el médico que cumple su deber profesional haciendo lo que el estado de la ciencia médica le indica hacer para intentar salvar ambas vidas, crea para la criatura (y para su madre) un riesgo que está permitido por el ordenamiento jurídico. Se trata de una conducta socialmente adecuada, y por lo tanto ya desde un comienzo no comprendida en el tipo penal" 52 , aunque se sepa que habrá de terminar con la vida del nasciturus. No puede decirse lo mismo, en cambio, del comportamiento dirigido directamente a provocar la muerte niño no nacido, aun cuando se realice con una finalidad terapéutica respecto de la vida de la ma$\mathrm{dre}^{53}$. Este último no es parte de ese riesgo permitido, sino que está expresamente prohibido por el Código Sanitario y el Código de Ética, por lo que tampoco puede estimarse justificado de conformidad con el art. 10 No 10 CP.

\footnotetext{
${ }^{51}$ Aunque no es un tema totalmente pacífico, gran parte de la doctrina entiende que las intervenciones curativas practicadas con arreglo a la lex artis y con resultado positivo no son penalmente típicas, a lo que otros añaden que la atipicidad no depende del éxito o no de la intervención, pues es un asunto que se juzga ex ante, y desde esta perspectiva "la atipicidad de la conducta del médico importa el reconocimiento de la especial valoración social de su función, que no es inhibida o tolerada, sino estimulada por la ley", Politoff et al. (2006) p. 270. En el mismo sentido Cury (2005) pp. 371-372; KüNSEMüller (1986) p. 263 (aunque lo fundamenta desde una perspectiva más bien subjetiva); Politoff et al. (2011a) p. 238. En el extranjero, por la opinión dominante, Mir Puig (2005) p. 488; Jаковs (1998) p. 27 y Roxin (1997) p. 372.

52 Van Weezel (2009) p. 206. También se inclinan por la atipicidad de la conducta Garrido (2007) p. 118, n. 225 y Bullemore y Mackinnon (2007) p. 52, aunque asignando un contenido mucho más amplio a la conducta amparable en la lex artis.

${ }^{53}$ En extenso sobre esta cuestión Ossandón (2011) passim.
} 
Ahora bien, en tanto esa prohibición solo dice relación con los límites del ejercicio legítimo de la profesión de médico, ella no excluye la posible concurrencia de otras causas de justificación ${ }^{54}$, lo ha de decidirse de conformidad con los requisitos que les son propios.

\section{f. Cumplimiento de un deber}

Las consideraciones recientes sirven también para descartar la concurrencia de esta causa de justificación, pues no se encuentra ninguna norma en nuestro ordenamiento jurídico que imponga el deber específico de realizar un aborto, aun cuando se trate de circunstancias extremas y de peligro para la vida de la madre.

En el caso de que no exista otra alternativa que matar al feto para salvar a la madre no se puede hablar de colisión de deberes ${ }^{55}$, ni siquiera si el autor se encuentra en posición de garantía respecto de la vida de la madre. En estas hipótesis, existe un deber, el de no matar. Pero no hay un deber de salvar, "pues el matar o lesionar al tercero -únicas conductas posibles para aquella salvación- no pueden contemplarse como conductas salvadoras exigibles (...) el no matar al tercero o no lesionarlo no pueden verse como 'omisión (tipo omisivo) de salvar' al individuo bajo nuestra tutela, con lo que se elimina la situación de colisión de deberes" 56 .

\section{ESTADO DE NECESIDAD. CONSIDERACIONES PREVIAS}

Por estado de necesidad en sentido amplio se entiende cualquier situación en la que se sacrifica un bien jurídico para salvar otro que se encuentra en peligro. "No constituye una institución jurídica unitaria, sino que es una mera situación de hecho que se proyecta sobre y produce consecuencias en las más diversas zonas o ramas de la realidad y la normatividad jurídicas y que esas ramas regulan independientemente de conformidad con su carácter y sus fines respectivos" 57 .

De conformidad con la teoría de la diferenciación ${ }^{58}$, dependiendo de sus características concretas, una situación de necesidad puede eliminar la antijuridicidad de la conducta cuando se evita un mal mayor que el que se causa, o puede que solo excluya la culpabilidad, si se trata de males equivalentes en gravedad o, eventualmente, se ocasiona un mal mayor. Estas posibilidades permiten afirmar que el estado de necesidad "destaca particular-

\footnotetext{
${ }^{54}$ Aunque generalmente se ha interpretado como excluyente de cualquier posibilidad de justificación. Así lo conciben, por ejemplo, Bascuñán (2004a) pp. 164 y 167; Cea (2004) p. 95; РRecht (1992) p. 516. Sobre la improcedencia de una interpretación tan extensiva del art. 119 CS vid. Ossandón (2011) pp. 128-129.

55 BAscuñán (2004a) p. 151 plantea el aborto terapéutico como una colisión de deberes de acción (deber de evitar daño al feto y de evitar daño a la mujer) en que no existe alternativa, o infringe uno o infringe ambos. Sería una situación equivalente, como colisión, a la del padre que ve a sus dos hijos en peligro de ahogarse, pero solo puede salvar a uno de ellos. Sin embargo, no compartimos que sea una colisión de deberes de acción, pues ese modo de ver las cosas prescinde de lo esencial: el deber de salvar a la madre (deber de acción) se enfrente al deber de no lesionar la vida del nasciturus (deber de omisión). Como dice Roxin (1997) p. 725, un deber de omisión lo infringe todo el que ataca un bien jurídico ajeno.

${ }^{56}$ Silva Sánchez (2003) p. 381-382, n. 109.

${ }^{57}$ Rivacoba (1995) p. 191.

58 Ampliamente dominante en Alemania y también en nuestro medio, vid. Rivacoba (1995) p. 197. Pero con detractores, especialmente, Gimbernat ([1974] 1990) y (1984).
} 
mente la delimitación fundamental en el sistema del delito, del injusto y la culpabilidad, así como las consecuencias a ellos vinculadas" 59 .

Solo en el caso del estado de necesidad justificante puede afirmarse que, cumplidas las condiciones, el orden jurídico aprueba el sacrificio de un bien jurídico a costa de otro, a cuyo titular se le impone el deber de soportar el daño, precisamente, porque de este modo se salva un bien mayor que el que se sacrifica.

Pero entre las situaciones de necesidad puede hacerse otro distingo según la vinculación que pudiera existir entre el sujeto afectado por la reacción necesaria y el peligro que la provoca. El supuesto normal de estado de necesidad es aquel en que la salvaguarda del interés amenazado requiere que el sujeto necesitado intervenga agresivamente contra un tercero ajeno a la fuente de peligro que amenaza, entonces estamos ante estado de necesidad agresivo. Pero también puede ocurrir que la salvaguarda del interés amenazado requiera que el sujeto que obra en estado de necesidad intervenga contra el sujeto de quien emana el peligro, en otras palabras, que el necesitado se defienda frente a un peligro que tiene su origen en la propia víctima del estado de necesidad. Estas situaciones se denominan estado de necesidad defensivo ${ }^{60}$.

La distinción es relevante en sus consecuencias, pues en el estado de necesidad defensivo el grado de lesión de los intereses ajenos susceptible de ser justificado debe ser superior que en el agresivo ${ }^{61}$. En particular, la prohibición de matar a otro, que en el estado de necesidad agresivo es absoluta, habría de matizarse en el estado de necesidad defensivo ${ }^{62}$. Se podría permitir, aunque bajo los más estrictos presupuestos y en términos absolutamente excepcionales, hasta matar para defenderse de un peligro generado por la propia víctima, aunque a ella no se le pueda imputar una agresión ilegítima (en cuyo caso estaríamos frente a una legítima defensa).

Ahora bien, la delimitación precisa del estado de necesidad defensivo está todavía lejos de ser un tema resuelto. Aunque existe coincidencia al estimar que la existencia de un nexo entre el peligro y el sujeto sobre el que recae la acción defensiva es lo que habilita al necesitado a la salvaguarda de sus bienes a costa de los ajenos en mayor medida, existen diversas corrientes doctrinales para definir en qué consiste ese nexo ${ }^{63}$. Algunos se conforman con una vinculación fáctica, de modo que el origen del peligro se atribuye al sujeto cuando sea posible constatar que este procede físicamente de su esfera de organización. Por el contrario, otros consideran que los deberes de tolerancia intensificados que implica el estado de necesidad defensivo solo pueden imponerse cuando existe una vinculación normativa entre el sujeto y la fuente del peligro, la que se configura como una forma -aunque atenuada- de

\footnotetext{
${ }^{59}$ Hirsch, H. J. (1992) "La regulación del estado de necesidad", en CGPJ, Jornadas sobre la Reforma del Derecho penal en Alemania, Madrid, pp. 59-60, cit. por Rivacoвa (1995) p. 191.

60 Sobre esta distinción BALdó (1994) p. 168 y ss.; Luzón (2006) pp. 617 y ss. y Roxin (1997) pp. 705-712.

${ }^{61}$ Cuando el tercero es "ajeno a la originación de la fuente de peligro", el principio es que cada uno asume los riesgos que sobre él se ciernen; solo pueden afectarse bienes ajenos en la medida en que el principio de solidaridad intersubjetiva lo permita, siempre que el interés salvaguardado sea relevantemente preponderante, BaLdó (1994) p. 169.

${ }^{62}$ Hirsch (2008) p. 1031.

${ }^{63}$ Particularmente analizadas por Coca (2011) pp. 6-14, sobre cuya exposición nos apoyamos para lo que sigue.
} 
responsabilidad por organización ${ }^{64}$. Volveremos sobre este punto al analizar si es posible invocar un estado de necesidad defensivo en el caso del aborto terapéutico.

\section{EL ESTADO DE NECESIDAD EN LA REGULACIÓN CHILENA}

En su redacción original nuestro Código Penal era sumamente restrictivo a la hora de conceder efecto justificante al estado de necesidad, pues solo permitía expresamente la afectación de la propiedad (art. 10 No 7 CP) o de la intimidad de la morada (art. 145 CP) para evitar un mal mayor que el causado para evitarlo.

Sin embargo, la Ley No 20.480, de 18 de diciembre de 2010 incorporó una nueva eximente de responsabilidad por estado de necesidad que puede llegar a tener efecto justificante. Dicha reforma se planteó en el contexto de la preocupación por la violencia que se ejerce contra la mujer, y entre otras modificaciones, pretendía incorporar una solución de inexigibilidad de otra conducta para las mujeres maltratadas que reaccionaren contra sus agresores ${ }^{65}$. Entendiendo que se trataba de ampliar la eximente de estado de necesidad exculpante, finalmente, el legislador optó por una regulación genérica del estado de necesidad al estilo de la que contempla el Código Penal suizo ${ }^{66}$, como una eximente genérica aplicable a cualquier delito y a cualquier sujeto, siempre que se cumplan los requisitos que se indican:

Art. 10. Están exentos de responsabilidad criminal:

11. El que obra para evitar un mal grave para su persona o derecho o los de un tercero, siempre que concurran las circunstancias siguientes:

$1^{a}$. Actualidad o inminencia del mal que se trata de evitar.

$2^{a}$. Que no exista otro medio practicable y menos perjudicial para evitarlo.

3a. Que el mal causado no sea sustancialmente superior al que se evita.

$4^{a}$. Que el sacrificio del bien amenazado por el mal no pueda ser razonablemente exigido al que lo aparta de sí o, en su caso, a aquel de quien se lo aparta siempre que ello estuviese o pudiese estar en conocimiento del que actúa.

Claramente, la disposición se refiere a una situación de peligro para un bien que solo puede evitarse causando un mal, es decir, una situación de necesidad. Pero el conflicto de intereses inherente al estado de necesidad excede aquí el ámbito de la justificación, pues la disposición libera de responsabilidad no solo a quien obre causando un mal menor, sino que se puede causar un mal equivalente o incluso uno mayor que el que se evita ${ }^{67}$. En efecto y a diferencia de lo que ocurría en la eximente del art. 10 No 7 -que con esta modi-

64 "El peligro es en alguna manera imputable a su 'propio' comportamiento organizador", BALdó (1994) p. 170.

${ }^{65}$ La que inicialmente se había planteado dentro del art. 10 № 9, como "obrar bajo amenaza de un mal grave e inminente".

${ }^{66}$ A propuesta del prof. Cury Unzúa, ver Informe de la Comisión Mixta, boletines No 4.937-18 y 5.308-18 refundidos, de 4 de octubre de 2010 .

${ }^{67}$ Le conceden efecto justificante y exculpante, SantibáÑez y Vargas (2011) p. 198; dudoso en cuanto a su posible efecto justificante Couso (2011) p. 235, pero no lo descarta, y abiertamente contrario a concederle este efecto, interpretándolo únicamente como causa de exculpación, Hernández (2011) pp. 270-271. 
ficación ha perdido todo interés-, el mal causado puede ser cualquiera, no tiene más límite que no ser sustancialmente superior al que se evita. Por lo tanto, habrá que comparar el mal causado y el que se evita, ponderarlos y, según eso, determinar si la eximente tiene valor justificante o exculpante.

A grandes rasgos, tal como acabamos de explicar, en los supuestos de estado de necesidad agresivo la conducta del necesitado solo puede considerarse justificada si el mal causado es menor que el evitado. Incluso, sería necesario que el bien protegido sea sustancialmente preponderante al lesionado para considerar autorizado el comportamiento ${ }^{68}$. Tratándose de un estado de necesidad defensivo, en tanto, el estándar de ponderación cambia; no exige preponderancia sino que se conforma con una equivalencia de los intereses en conflicto ${ }^{69}$.

Fuera de estos casos, si el mal causado solo es superior de modo insignificante, si es equivalente o incluso si es superior en cierta medida -pero no sustancialmente superior- al mal que se trata de evitar, el estado de necesidad operaría como una eximente respecto de la culpabilidad. Es decir, una situación en que la conducta sigue estando prohibida, pero no resulta exigible una actuación conforme a Derecho por las particulares circunstancias de peligro en que se encuentra la persona necesitada.

Los límites entre todas estas posibilidades así como los criterios para la ponderación entre los males involucrados son materias de extrema complejidad en las que no podemos detenernos por ahora. Por lo demás, son cuestiones muy poco estudiadas por la doctrina chilena, dada la estrecha regulación que en nuestra legislación se confería al estado de necesidad, situación que habrá de cambiar tras la incorporación de este nuevo No 11 del art. 10 CP.

\section{EL ESTADO DE NECESIDAD EN RELACIÓN CON EL ABORTO}

En aquellas legislaciones en que se excluye la punibilidad del aborto por razones terapéuticas, esta situación es mayoritariamente considerada un supuesto especial de estado de necesidad justificante, aunque con requisitos parcialmente diversos del estado de necesidad general. Las diferencias con aquel se darían, fundamentalmente, por el hecho de que el peligro no es actual o inminente, o al menos, no tiene la urgencia propia de una situación de necesidad; y además, porque requiere que la intervención sea realizada por un médico con el consentimiento de la mujer embarazada. Pese a esas diferencias, el aborto no punible por motivos terapéuticos, reconocería como fundamento el estado de necesidad y produciría sus mismos efectos ${ }^{70}$.

\footnotetext{
${ }^{68}$ Así se requiere en el ordenamiento jurídico alemán, en el $\$ 34$ StGB. Una sólida fundamentación de esta exigencia, de conformidad con los principios de autonomía y solidaridad y su reconocimiento en nuestro modelo social, en Baldó (1994) passim. De acuerdo con ese planteamiento, Silva Sánchez (1999) p. 157. En la misma línea, Mir Puig (2005) L 17/26, p. 452, criticando la interpretación de la doctrina española, que estima justificada la salvación del bien superior, pese a que "en los casos de poca o hasta mínima diferencia entre los bienes en conflicto resulta político-criminalmente excesivo que el Derecho apruebe sin más la perturbación del orden jurídico y, en su caso, la intromisión en derechos ajenos”.

${ }^{69}$ Por todos, Bascuñán (2004b) p. 70.

70 En Argentina, en esta línea se pronuncian, por ejemplo, Fontán (1995) II, p. 234; LAJe (2003) pp. 289 y 293; Massaglia (2005) pp. 67-68; Soler (1978) p. 106; Rivacoba (1995) pp. 260-263. En Perú, Castillo (2008) pp. 1048-1049.

En España, la mayoría también lo estima una causa de justificación. Por todos, Muñoz Conde (2007) p. 83.
} 
Pero salvo en los ordenamientos en que se asigna claramente una determinada función dogmática a esa hipótesis ${ }^{71}$, su naturaleza ha sido discutida y se le han asignado diversos roles: causa de atipicidad, de justificación, de exculpación o de exclusión de la punibilidad $^{72}$.

En nuestro país, como advertíamos, la antigua regulación que contenía el Código Sanitario relativa al aborto terapéutico era, mayoritariamente, considerada una hipótesis de estado de necesidad ${ }^{73}$. Con posterioridad pero todavía antes de la reforma del art. 10 No $11 \mathrm{CP}$, parte de la doctrina ha insistido en su justificación como un caso paradigmático de estado de necesidad defensivo ${ }^{74}$.

La verdad es que en los casos de aborto terapéutico estamos ante un conflicto de intereses en que la lesión de uno de ellos aparece como el medio necesario para salvar el otro. Se trata, por ende, de un estado de necesidad que bien puede incluirse en los términos de lo estipulado en el actual art. 10 No 11 CP. Pero lo que queda por resolver es el rol dogmático preciso que tendrá esta eximente, pues ya hemos visto que no toda situación de necesidad tiene efecto justificante. Ello depende, en gran medida, del juicio de ponderación que resulte entre los intereses en conflicto, en virtud del cual el ordenamiento jurídico puede autorizar una conducta o solo disculparla.

Resulta necesario, por tanto, revisar más detalladamente lo que sucede en el denominado aborto terapéutico para decidir si esta situación de necesidad puede considerarse causa de justificación, lo que significaría entender que en esos casos el aborto no es un injusto penal y que se trataría de la privación legítima de la vida del feto; o si, por el contrario, se reputa que estamos ante una situación de exculpación, pues entonces el aborto "constituiría una privación ilegítima de la vida de otro, pero que no resulta penalmente sancionada porque el responsable actuó en situación de inexigibilidad de otra conducta"75.

Incluso hay quienes entienden que entonces la conducta es atípica, así Valle y Quintero Olivares (2009) p. 97. La solución sería la misma luego de la modificación estipulada por la LO 2/2010, en este sentido, JUANATEY (2010) p. 103.

${ }^{71}$ En Alemania, el $\$$ 218a. inciso segundo se refiere a la indicación terapéutica afirmando que entonces "la interrupción del embarazo no es antijurídica", por lo que es concebida como una causa de justificación. En este sentido, Eser (2010) $\$ 218 a n^{\circ}$ marginal 21; Fischer (2010) $\$ 218$ a n ${ }^{\circ}$ marginal 13; Gropp, (2003) Vor $\$ \$$ 218 ff. número marginal 2; KindhäUSER (2009) \$ $6 \mathrm{n}^{\circ}$ marginal 7, y SAtZger (2008) p. 430.

72 Acerca de la discusión sobre su naturaleza en España, vid. por todos, Luzón (1989) pp. 782-783, y especialmente Laurenzo (1990) p. 143 y ss., quien destaca la diversidad de opiniones doctrinales y la originalidad de algunas de ellas. Por lo demás, cuestiona que las indicaciones, en general, configuren auténticas causas de justificación por estado de necesidad pues no es posible afirmar una clara diferencia valorativa entre los intereses en conflicto, salvo el caso de riesgo vital, pp. 159, 235 y ss. En Argentina, sobre la posibilidad de considerarlo con carácter exculpatorio y no justificante, Terragani (2000) p. 460. Niegan la posibilidad justificante Barra (1996) p. 126 y Lennon (1993) p. 64. En Perú, el art. 119 CP sobre aborto terapéutico ha sido calificado como un supuesto de estado de necesidad exculpante por Caro John (2010) p. 89 y García Cavero (2010) p. 202; y como una causa de exclusión de la punibilidad por Bramont-Arias y García (1998) p. 94.

73 Cousiño (1979) pp. 353, 425-430; LABAtut (2007) p. 128 y, particularmente riguroso, EtcheberRy, Derecho penal. PE, III, $1^{\text {a }}$ ed., Santiago, Carlos E. Gibbs A., Editor, 1965, pp. 101-102 (referido al art. 226 del DFL 2.226 de 1931) y 2a ed., Editora Nacional Gabriela Mistral, 1976, pp. $73-76$ (referido al art. 119 del DFL 725 de 1967).

${ }^{74}$ En este sentido Bascuñán (2004a) p. 173. De acuerdo, Horvitz y Soto Piñeiro (2007) p. 83.

75 García Cavero (2010) p. 199, destacando las diferencias entre una y otra. 
Antes de adentrarnos en el problema de la ponderación de los intereses en conflicto, sin embargo, nos haremos cargo de la tesis de que el aborto terapéutico sería una hipótesis de estado de necesidad defensivo, pues en ese caso se podría justificar la conducta aun cuando se considere que la vida del no nacido y la de la madre tienen un valor equivalente.

\section{IMPROCEDENCIA DEL ESTADO DE NECESIDAD DEFENSIVO}

La particularidad del estado de necesidad defensivo es que permite flexibilizar el juicio de ponderación cuando la víctima es quien genera el peligro contra el cual se reacciona, aun cuando sea inocente del mismo ${ }^{76}$. "Nadie tiene por qué tolerar el sacrificio de sus intereses si puede evitarlo atacando la fuente del peligro, aunque ello implique la afectación de intereses de un inocente, con tal que esos intereses afectados tengan un peso específico menor o equivalente al peso específico de los intereses que se protege" 77 . Como este es un derecho que se tiene respecto de cualquiera, también podría invocarse con respecto al feto, se le considere o no como persona ${ }^{78}$.

Aunque para enfrentar el peligro provocado por la presencia o permanencia del feto no puede invocarse una legítima defensa, pues no existe una "agresión" (el feto no es capaz de acción), quienes defienden esta posición sostienen que como el nasciturus no es ajeno a la creación del peligro, tampoco cabe aplicar las exigencias de ponderación del estado de necesidad agresivo. Estaríamos ante un estado de necesidad defensivo, por el cual la conducta abortiva bien puede considerarse justificada dado que la vida del feto es un interés, como mucho, equivalente al de la madre.

Sin embargo, esta tesis está lejos de ser lo obvia que pretende.

En primer lugar, porque no está tan claro que sea siempre el feto quien genere la situación de peligro. La solución del estado de necesidad defensivo no se ajusta a los conflictos que no se pueden retrotraer a la especial constitución del niño. Como advierte JаковS $^{79}$, puede darse la situación inversa, que sea la madre la que pone en peligro al hijo, como cuando la desgracia no se basa en un desarrollo defectuoso del niño, sino en una constitución poco favorable al parto de la madre ${ }^{80}$.

Pero también, especialmente, porque resulta controvertido el grado de vinculación con el peligro que debe mantener aquel que resulta ser el afectado por la acción de necesi-

\footnotetext{
${ }^{76}$ Bascuñán (2004b) p. 68, n. 44 cita el ejemplo de Robert Nozick conocido como el caso de la amenaza inocente: si alguien levanta a un tercero y lo arroja contra usted al fondo de un pozo profundo, ¿puede usted usar su pistola de rayos para desintegrar el cuerpo que cae antes de que se estrelle y lo mate a usted, suponiendo que la persona lanzada pudiera sobrevivir a la caída sobre usted?

77 Bascuñán (2004a) p. 173.

78 Por esta razón BAscuñán (2004a) p. 173, considera que el art. 119 del Código Sanitario es inconstitucional, en cuanto afecta el principio de igualdad ante la ley al denegar a la mujer embarazada respecto del feto el derecho que tiene cualquier persona respecto de otra. Sin embargo, como veremos, esa disposición se refiere solo al ejercicio de la medicina, por lo que en su crítica este autor le estaría asignando un efecto general que no le corresponde.

${ }^{79}$ Jаковs (1997) p. 506, n. 44, criticando la solución de Roxin, pues responsabiliza siempre al nonato del peligro.

${ }^{80}$ Como ocurriría cuando el peligro procede de una estrechez del canal del parto de la madre, a la que entonces podría considerársela como una quasi agressora injusta de su hijo, Horvitz y Soto PiñeIro (2007) p. 83, n. 14. Sobre la discusión particular a propósito de la perforación o embriotomía, Martínez (2006) pp. $482-492$.
} 
dad, para poder afirmar que el estado de necesidad es defensivo. Recordemos que si la conducta de reacción ante el peligro es considerada defensiva, y por ende, justificada, no cabe la posibilidad de oponerse legítimamente a ella. Es decir, existe un deber de tolerarla.

A este respecto, entendemos que no basta con un mero dato fáctico, causal; no basta con el hecho de estar "en el lado de la fuente de peligro", estar "implicado en la fuente de peligro" o que el peligro "parta de su esfera”. Que el peligro proceda físicamente de la esfera de un determinado sujeto, como dato meramente naturalístico, no debería ser considerado relevante para fundamentar responsabilidad alguna ni justifica la imposición de un deber de tolerancia ${ }^{81}$ : la imposición o la distribución de cargas en la resolución de conflictos jurídicos en situación de necesidad no se puede hacer prescindiendo del sinalagma que precisamente fundamenta ese procedimiento en el Derecho penal moderno -libertad por organización y responsabilidad por organización- y de su ampliamente aceptado principio limitador -el principio de solidaridad- ${ }^{82}$.

En consecuencia, a la hora de decidir si la persona sobre quien recae la reacción necesaria es o no es un tercero ajeno al peligro, se deben considerar criterios normativos. Solo deja de ser ajeno al peligro aquel a quien se le puede atribuir la creación de ese peligro; quien es competente por el peligro generado, aunque no sea penalmente responsable por ello.

Esta exigencia se explica porque la flexibilización del juicio de ponderación propio de un estado de necesidad defensivo constituye un nivel valorativo intermedio, entre la legítima defensa y el estado de necesidad agresivo. En la legítima defensa, la actuación agresiva dolosa genera plena responsabilidad y desencadena un deber de tolerancia absoluto. En el estado de necesidad agresivo el afectado por la acción de necesidad es un tercero ajeno, que no es competente por el peligro, al que se le imponen deberes de tolerancia mínimos porque solo se puede invocar para ello un principio de solidaridad general. El estado de necesidad defensivo, en tanto, legitima la afectación de un bien que puede tener un valor equivalente al que se salva, y en ese nivel, el fundamento ha de ir más allá de la solidaridad y radicarse en alguna forma de responsabilidad. Así, se ha llegado a afirmar que "el estado de necesidad defensivo en sentido estricto debe quedar reservado para supuestos donde sea posible afirmar, al menos, la imputación objetiva y subjetiva mínima del peligro que amenaza al necesitado" 83 , y que "el estado de necesidad defensivo no está emparentado realmente con el estado de necesidad, sino que comparte, más bien, la estructura de la legítima defensa. Ya que el que crea la situación de peligro ha realizado un acto de organización, este

${ }^{81}$ Robles (2010) p. 449.

82 Coca (2011) p. 30, y agrega que "es absolutamente arbitrario distinguir -también a los efectos de imponer deberes de tolerancia- entre sujetos por la mera vinculación causal-mecánica, arbitrariedad que convertiría esos subsistemas de atribución de responsabilidad penal en sistemas irracionales, vinculados a aquello a lo que algunos no han dudado en llamar 'la peste del Derecho', la causalidad” (p. 31).

${ }^{83}$ Robles (2010) p. 449. En el mismo sentido Baldó (1994) pp. 60-61, 134-136, habla de una posición de responsabilidad preferente, aunque no sea responsabilidad completa. Cercano, Jаковs (1997) p. 521, afirma que el estado de necesidad defensivo únicamente concurre cuando la víctima de la intervención es responsable del peligro, pero se conforma con un principio de responsabilidad atenuado al que denomina principio de ocasionamiento (p. 421); y en una línea similar a este, Renzikowski, Joachim, Notstand und Notwehr, Berlín, Dunker \& Humbolt, 1994 y PAWLIK, Michael, Der Rechtfertigende Notstand: zugleich ein Beitrag zum Problem strafrechtlicher Solidaritätspflichten, Berlin, Walter de Gruyter, 2002, cit. por Coca (2011) pp. 9-10. 
resulta competente por el peligro generado aun cuando no sea penalmente responsable por ello y, en consecuencia, se le atribuye el deber de eliminarlo, de asumir los costes de los daños que produzca o, en caso necesario, de soportar la eliminación del peligro por parte del afectado" 84 .

Sobre la base de estos principios materiales quedan mejor delimitados los supuestos de estado de necesidad defensivo, y es fácil concluir que el aborto terapéutico no resulta comprendido en esta situación. Al nasciturus no puede imputársele, ni siquiera de modo objetivo, la situación de peligro respecto de la cual está vinculado solo de modo fáctico, o ni siquiera eso, pues él se encuentra en una posición similar a la de la madre, es decir, es tan víctima como ella ${ }^{85}$. De este modo, "dado que el concebido no agrede (ni en los términos de la legítima defensa, ni en los del estado de necesidad defensivo) cualquier acción contra él solo podría pretender ampararse en un estado de necesidad agresivo" 86 .

Descartado el recurso al estado de necesidad defensivo, corresponde hacernos cargo de la valoración de los intereses en conflicto, para determinar si el aborto terapéutico, o incluso por otros motivos, puede considerarse justificado como un estado de necesidad agresivo. El análisis va a depender, fundamentalmente, de cómo se valore la vida del no nacido.

\section{LA PONDERACIÓN DE LOS INTERESES EN CONFLICTO}

La ponderación de los intereses en conflicto en el estado de necesidad tiene una doble función. Por una parte, se debe establecer si el mal causado no es sustancialmente mayor que el evitado, presupuesto indispensable para constatar la existencia de la eximente; y por otra, es necesaria para determinar su naturaleza, pues la ponderación se erige como fundamento de su efecto justificante, cuando el interés salvado es esencialmente más valioso que el lesionado ${ }^{87}$.

Nuestro Código Penal se refiere a una comparación entre el mal causado y el mal evitado, y en este sentido coincide con la opinión doctrinal de que la ponderación no se puede limitar a la comparación del valor abstracto de los bienes en conflicto, sino que han de incorporarse otros elementos que inciden en la situación de necesidad. Por ejemplo, tiene relevancia la intensidad de la lesión al bien jurídico, la posibilidad de repararlo, el grado o proximidad de las situaciones de peligro, posiciones de deberes especiales, la importancia individual del daño evitado y del causado, el origen del peligro, etc. ${ }^{8}$. Pero no cabe duda de que el criterio del valor de los bienes jurídicos está presente de modo muy relevante, pues la relación entre ellos constituye la base y el material de la ponderación y su distinto valor puede llegar a tener un peso decisivo en el resultado ${ }^{89}$.

\footnotetext{
${ }^{84}$ García Cavero (2008) pp. 484-485.

${ }^{85}$ Algunas de las situaciones que suelen invocarse como indicaciones en que sería necesario el aborto, ni siquiera se originan físicamente en el feto, como los casos de infección ovular con sepsis grave, eclampsia, alteraciones autoinmunes que no responden al tratamiento médico, embolia de líquido amniótico, etc.

${ }^{86}$ Silva Sánchez (2007) p. 14.

${ }^{87}$ Por todos Martínez (2006) p. 153 y Laurenzo (1990) pp. 222-223.

88 Sobre esto Roxin (1997) pp. 672 y ss.

${ }^{89}$ Martínez (2006) p. 335-338
} 
En el caso del aborto terapéutico este suele ser el argumento central: como la vida del feto valdría menos que la de la madre, está justificado el aborto para salvarla a ella ${ }^{90}$. Para algunos autores, también la salud física o psíquica de la mujer tendría esa primacía valorativa, lo que permitiría la misma solución justificante ${ }^{91}$, que incluso ha sido propuesta en el contexto de otras indicaciones para el aborto ${ }^{92}$.

La tesis mayoritaria de que la vida del no nacido tiene menor valor que la vida de la madre, como persona independiente, se sustenta en primer lugar -en forma tan contundente que suele ser el único argumento invocado-, en la diversidad de penas con que se sancionan los delitos de homicidio y aborto ${ }^{93}$.

Sin embargo, la absoluta predominancia que se le asigna a la penalidad del aborto se contrapone con la idea general de que este criterio, con ser un punto de apoyo para el juicio de ponderación, no debe ser más que un criterio orientativo que no se puede sobrevalorar ${ }^{94}$. La pena puede estar determinada por muchos otros factores, como la modalidad de ataque al bien jurídico, el carácter subsidiario del Derecho penal frente a otros sistemas de control social, las exigencias sociales de castigo (como ocurre con los incrementos sostenidos de pena en los delitos patrimoniales por situaciones de inseguridad ciudadana) ${ }^{95}$, etc.

En particular, la menor penalidad del delito de aborto estaría fuertemente condicionada por variados factores. Entre otros, como resabio histórico de la consideración del feto como parte del cuerpo de la madre o como un ser que no sería humano hasta poseer ciertas propiedades externas. Puede considerarse también un diverso juicio de reproche, toda vez que quien mata a otro ser humano al que puede fácilmente confrontar como un igual, pues así se presenta ante sus sentidos, es más culpable que quien mata a una persona a la que no puede reconocer sensorialmente. En la actualidad, resulta de particular relevancia que el aborto no provoque la misma sensación de inseguridad que el homicidio pues no es un delito respecto del cual los ya nacidos puedan ser víctimas ${ }^{96}$.

Algunos pretenden que la diversidad valorativa se apoyaría materialmente en que la vida de la madre, como realidad actual desarrollada, es más valiosa que la del feto, "que es

\footnotetext{
${ }^{90}$ Riguroso en la ponderación ETCHeBerRy (1965) pp. 101-102, referido al art. 226 del DFL 2.226 de 1931, y Etcheberry (1976) pp. 73-76, referido al art. 119 del DFL 725 de 1967.

${ }^{91}$ Cousiño (1979) p. 428 hacía prevalecer la salud física o psíquica de la mujer, frente a "lo aleatorio del fruto de la concepción, de quien nada sabemos", opinión que el conocimiento científico actual ha tornado obsoleta.

92 Bascuñán (2004a) pp. 167 y ss. lo plantea, en consonancia con la jurisprudencia del Tribunal Constitucional Federal alemán, como un problema de exigibilidad diferenciada: la exigibilidad del deber de tolerar el embarazo cesa en cualquier situación en la que el embarazo origine para la mujer el sacrificio de sus intereses por encima del margen y grado de afectación inherente a todo embarazo. Pero tras esta formulación sigue existiendo, como el mismo autor reconoce, un conflicto de intereses que se resuelve luego de un juicio de ponderación, dependiendo del peso específico que se le asigne a cada uno de esos intereses. Por eso, por ejemplo, considera "difícil admitir con base exclusiva en la Constitución la preponderancia de intereses patrimoniales de la mujer frente al interés constitucional en la preservación de la vida del feto" (p. 178).

93 Vgr. Etcheberry (1998) p. 107, y Gimbernat ([1974] 1990) p. 59

${ }^{94}$ Jakobs (1997) p. 504; Roxin (1997) p. 683, y Martínez (2006) pp. 380-383 quien constata práctica unanimidad en esta idea.

95 En este sentido García (2010) p. 200.

96 “Advierto que todos los que están a favor del aborto ya han nacido" decía Ronald Reagan.
} 
una eventualidad de posterior desarrollo vital" 97 . Con todo, no puede sostenerse coherentemente que en el delito de aborto se protege la vida del no nacido, para después, al enfrentar el supuesto particular de aborto terapéutico, deponer esa afirmación transformando esa vida en una mera esperanza o perspectiva de vida. El nasciturus vive y ese es el bien jurídico penalmente protegido.

Dado que el conflicto que subyace al aborto terapéutico se produce entre intereses constitucionalmente protegidos, resulta indispensable recurrir a las valoraciones que contiene nuestra carta fundamental.

\section{9. ¿DERECHO A LA VIDA DEL NIÑO NO NACIDO?}

Es de sobra conocido que la Constitución política se refiere expresamente al no nacido en su artículo 19 No 1 inciso segundo. Luego de asegurar a todas las personas el derecho a la vida y a la integridad física y psíquica, dicha disposición agrega que la ley protege la vida del que está por nacer. Esta especial mención que se hace del que está por nacer, lejos de establecer claridad sobre su estatuto normativo, ha sido objeto de diversas interpretaciones.

Mayoritariamente la doctrina chilena considera que el que está por nacer es persona, con igual dignidad y derechos que las demás personas; y que tiene, por tanto, derecho a la vida al igual que los seres humanos nacidos ${ }^{98}$. Pero esta misma regulación ha servido también para negar que el nasciturus tenga un derecho constitucional a la vida, considerando que únicamente se le garantizaría la protección legal de su vida99. Es decir, solo podría considerársele un objeto que merece especial protección legal, pero no un sujeto de derechos.

\footnotetext{
97 Creus (1999) p. 63. En el mismo sentido Terragani (2000) p. 460 entiende que el Derecho se inclina por proteger la vida de la madre "considerando que se trata de una existencia independiente frente a una que, por el momento, solo constituye una perspectiva”.

${ }^{98}$ Cea (2004) pp. 47, 93 y ss.; Corral (2005) pp. 44-45; Diez (1999) p. 126; Doyharcabal (1994) pp. 314315; Evans de la Cuadra (2004) p. 113; Evans Espiñeira (2000) p. 48; Fermandois (2004) pp. 96 y 113 ; Fuenzalida (1998) p. 834-837; Lyon (2007) pp. 45, 94 y ss.; Molina Guaita (2008) pp. 202-204; Nogueira (1997) p. 9; Nogueira (2007) p. 313; Núñez Leiva (2010) pp. 79-83; Núñez Poblete (1998) pp. 50-51, 57-58; Precht (1992) p. 516 y ss.; Rozas (1989) p. 729; Rodríguez (1992) p. 380; Silva MacIver (1995) p. 193; Soto Kloss (1991) pp. 139-141; Ugarte (2006) pp. 522-523; Varela (1990) p. 197; Verdugo/PfeFFer/Nogueira (1994) p. 199; Vivanco (2001) p. 478, y Zapata (1988) pp. 382-383. Es también la opinión del Tribunal Constitucional, en sentencia Rol 740-07, de 18 de abril de 2008, considerando 54º.

Parcialmente diferente es la postura de Figueroa Yáñez (2001) pp. 143 y 145, pues entiende que el nasciturus es sujeto de derechos, titular del derecho a la vida, pero solo desde su implantación en el útero (antes de eso puede ser considerado una cosa, homologándose a su status aunque con restricciones). Pese a que técnicamente todavía no es una persona (advierte también que "es en verdad persona aunque el ordenamiento jurídico le niegue tal carácter”, p. 150).

${ }^{99}$ Bascuñán (2004b) p. 54 y ss.; Bordalí y Zúñiga (2009) p. 177; Figueroa García-Huidobro (2007) p. 115 y ss.; Gómez (2005) p. 310; y MaYer (2011) p. 64 y ss. Es también la línea de la doctrina penal, así ETCHeberry (1998) p. 92 y Garrido (2007) p. 25. También, aunque en sentido crítico, Guzmán Brito (2001) pp. 92 y 192 y MOHOR (1988) p. 44.

Aldunate (2008) p. 150, considera que no puede afirmarse la calidad de persona desde el momento de la concepción, por lo que entiende que el que está por nacer sería "solo titular del derecho de protección previsto por esta disposición [art. 19 No 1 i. II]" (el destacado es nuestro). Sin embargo, resulta paradójico que el nasciturus sea considerado titular de un derecho si carece de personalidad, razón por la cual BAsCuñán (2004b) p. 64, le niega la posibilidad de recurrir a los procedimientos de protección o amparo.
} 
Se trata de una discusión fundamental y que condiciona todo el debate sobre el aborto $^{100}$, pero como ha sido un tema latamente desarrollado por diversos especialistas, aquí nos limitaremos a enunciar de modo muy breve los principales argumentos esgrimidos desde una u otra posición.

\section{a. Argumentos para negar la Personalidad Del No NACido y SU DEReCho A} LA VIDA

1. De acuerdo con el artículo $1^{\circ} \mathrm{CPR}$, las personas nacen libres e iguales en dignidady derechos, lo que significa que la personalidad se adquiere con el nacimiento ${ }^{101}$.

2. El artículo 19 No 1 CPR hace un tratamiento diferenciado respecto del nasciturus, pues en su inciso primero asegura a todas las personas el derecho a la vida; mientras que el segundo establece que la ley protege la vida del que está por nacer. Si el nasciturus fuese persona y se le reconociera constitucionalmente un derecho subjetivo constitucional a la vida, entonces no tiene sentido destinarle un inciso especial diferente del tratamiento general del derecho a la vida; ese inciso segundo sería superfluo ${ }^{102}$.

3. El inciso segundo del No 1 del artículo 19 CPR consagra solo un deber de protección legal de la vida del nasciturus que no significa reconocer que tiene derecho a la vida. De un deber de protección no se infieren derechos, y la Constitución ordena proteger la vida, no el derecho a la vida del nasciturus ${ }^{103}$.

4. La intención del constituyente, que en relación con la vida del nasciturus no pretendía consagrar una prohibición absoluta de atentar contra ella, como si lo haría

100 Algunos consideran que no es más que una estrategia argumental, que se limita a concentrar la discusión en "un debate que es circular y que no es decisivo para el tratamiento de los problemas prácticos involucrados”, Bascuñán (2004a) p. 158, en la línea de los planteamientos de Thomson (1983) p. 9-32. Sin embargo, la importancia de esta discusión se advierte en la opinión de autores a quienes no se puede imputar el recurso a una "estrategia argumental". Así Dworkin (1994) aunque desecha la cuestión de la personalidad en razón de su ambigüedad, p. 34, luego es muy enfático para concluir que si el feto fuera una persona "constitucional" se acabaría la discusión, debería ser protegido igual que las demás personas, pp. 146-147; y JАKOBs (2000) pp. 159-168 concluye que solo si el feto no es considerado persona puede resultar justificado el aborto en ciertas hipótesis. Por lo demás, "la propuesta de excluir el problema de la calificación de la persona del debate sobre la protección jurídica de la vida, tiene como resultado la retirada del orden jurídico de la cobertura de tutela de ciertos segmentos de la vida humana" Corral (2005), p. 49. Reducida a la categoría de bien, cuando esa vida se opone al ejercicio de un derecho fundamental de un individuo que sí es reconocido como persona, la decisión viene ya resulta a favor del derecho. Aunque no lo considere "decisivo", es obvio que el propio Bascuñán habría llegado a conclusiones diversas en relación con las indicaciones que permitirían el aborto, si al ponderar los intereses involucrados en un lado de la balanza tuviera un derecho a la vida y no un mero interés en protegerla.

101 Garrido (2007) p. 25; Politoff/Matus/Ramírez (2004b) p. 22, y Guzmán Brito (2001) p. 192, quien aplica esa exigencia solo a las personas naturales, y no tiene inconveniente en considerar personas a las personas jurídicas.

102 Cfr. Aldunate (2008) p. 150; Bascuñán (2004b) p. 54; Etcheberry (1998) p. 88; Figueroa GarcíaHuidobro (2007) p. 118; Gómez (2005) p. 310. Menos enfáticos, Horvitz y Soto Piñeiro (2007) p. 89, según los cuales, "desde la perspectiva constitucional es posible sostener el estatus de derecho subjetivo público de los derechos de la mujer, el que es restringido y afectado por el hecho del embarazo, mientras que no aparece tan claro ni evidente dicho estatus para la vida del nasciturus (...)", aunque en n. 19 se inclinan por negar el carácter de persona al nonato.

${ }^{103}$ En este sentido Figueroa García-Huidobro (2007), p. 120 y Монor (1988) p. 51. 
respecto de la vida del nacido ${ }^{104}$. En particular, la redacción del artículo 19 No 1 refleja la posición mayoritaria dentro de la comisión en orden a rechazar la proscripción absoluta del aborto ${ }^{105}$.

5. En una interpretación sistemática sobre el significado atribuido por la Constitución al concepto persona, por el sentido en que se lo emplea en sus diversas disposiciones, se concluye que en ninguno de esos casos puede hacerse extensivo al aún no nacido ${ }^{106}$.

6. Sostener que el nasciturus se encuentra contenido en los dos incisos del art. 19 No $1 \mathrm{CPR}$, implicaría conferirle una protección mayor que a los seres humanos nacidos: mientras que respecto del primero se estaría estableciendo tanto el derecho constitucional a la vida como un mandato constitucional de protección legal, respecto de los seres humanos nacidos solo se establecería el primero. De este modo se infringe el principio de igualdad reconocido en el artículo 19 No 2 de nuestra Constitución ${ }^{107}$.

7. Para el resto de nuestro ordenamiento jurídico persona es el ser humano nacido. El Código Civil chileno en su artículo 74, dispone expresamente: La existencia legal de toda persona principia al nacer, esto es, al separarse completamente de la madre. En consecuencia, solo con el nacimiento comienza la existencia legal de la persona; antes de dicho evento no existe una persona desde un punto de vista legal ${ }^{108}$. Dado que la Carta fundamental no define qué ha de entenderse por persona, debería atenderse a la regulación infraconstitucional para precisar su contenido ${ }^{109}$

8. Si el feto fuera persona serían inconstitucionales todas las disposiciones penales relativas al delito de aborto, pues no debería haber diferencia alguna entre dar muerte a una persona antes o después del parto ${ }^{110}$.

9. De que el nasciturus sea un ser vivo no se desprende que tenga derecho a la vida ${ }^{111}$. La titularidad del derecho a la vida es consecuencia de decisiones políticas, no del mero hecho de ser. Se trata, en definitiva de una cuestión constitucional, no biológica ${ }^{112}$.

\footnotetext{
${ }^{104}$ Cfr. Bascuñán (2004b) p. 56 y ss., y Figueroa García-Huidobro (2007) p. 124, aunque el mismo estima que no es buen criterio de interpretación recurrir a las actas.

105 Frente a la propuesta de GuzMán Errázuriz, el resto de la comisión manifestó su opinión decididamente contraria a una prohibición absoluta del aborto.

106 Figueroa García-Huidobro (2007) p. 118, basado en el método que empleó la Corte Suprema de Estados Unidos en el caso Roe vs. Wade y considerando las 63 oportunidades en que se emplea la palabra persona en nuestra Constitución.

${ }^{107}$ Mayer (2011) p. 65.

108 Etcheberry (1998) p. 92; Figueroa García-Huidobro (2007) p. 118, y Guzmán Brito (2001) p. 193, quien incluso estima superflua la declaración de que las persona nacen (...) contenida en el art. $1^{\circ}$ inc. $1 \mathrm{CPR}$, pues en virtud del art. 74 CC si no han nacido, no son personas.

109 "La doctrina mayoritaria no ha proporcionado razones atendibles de por qué habríamos de hacer caso omiso de esas reglas", Figueroa García-Huidobro (2007) p. 124.

${ }^{110}$ ETCHEBERry (1998) p. 92.

${ }^{111}$ El objeto de un derecho a algo no puede ser una cosa o una conducta de su titular, sino la conducta de terceros que puede regularse jurídicamente, Figueroa García-Huidobro (2007), p. 120.

${ }^{112}$ Figueroa García-Huidobro (2007), p. 123. Este argumento se basa en la distinción entre los conceptos de ser humano y persona. El primero corresponde a un concepto biológico referido a los miembros de la especie homo sapiens, mientras que el segundo es un concepto moral (ser que es un fin en sí mismo, que posee dignidad y exige respeto). En esta línea se ubican planteamientos extremos como el de Singer quien define a las personas como aquellos seres que poseen autoconciencia y racionalidad actual, de lo que resulta que muchos seres
} 
10. Tratándose del embrión, su identidad genética humana no significa que se trate de un individuo de la especie humana. Tanto por su potencialidad, pues sus células aún no han sufrido el proceso de diferenciación y especificación que caracteriza el desarrollo del organismo humano ${ }^{113}$, como porque no puede afirmarse que el embrión preimplantacional posea la potencia de desarrollarse, en el sentido preciso de que posea la capacidad intrínseca y autónoma de transformarse en ese ser humano individual. Esa supuesta capacidad, propuesta por el paradigma genético, es controvertida por el paradigma alternativo, esto es, el paradigma epigenético. Según este, "el comportamiento del organismo en la etapa embrionaria no está codificado en el ADN sino en la red de interacciones celulares de carácter ambiental, lo cual incluye desde luego al genoma pero no se limita a él"114. Aunque en el cigoto exista un material genético nuevo, se afirma que "el ADN no constituye el organismo. El organismo se constituye por su todo en interrelación integrada" 115 .

11. En su etapa primera de desarrollo ni siquiera hay un individuo, pues el ovocito fecundado puede tener diversos destinos: perderse, transformarse en una mola, dar lugar a varios individuos (por gamelación), etc. ${ }^{116}$.

12. De la potencialidad de llegar a ser indiscutidamente una persona no se deduce la identidad entre el embrión (preimplantacional) y el ser humano nacido. "Todos los árboles y las flores fueron antes una semilla; de ahí no se deduce que las semillas sean árboles o flores. Pretender lo contrario es incurrir en una falacia retrospectiva"117.

humanos (incluso ya nacidos) quedan fuera de esta clase (embriones, niños, comatosos, dementes, etc.). Afirma que "pretender que todo ser humano tiene derecho a la vida solo por ser miembro biológico de la especie homo sapiens es convertir a la misma relación de membresía en base de derechos. Y esta tesis es tan indefendible como hacer de la pertenencia a una raza la base de los derechos”, Singer (2003) p. 237.

113 "La potencialidad del embrión es la demostración de su falta de individualidad”, Bascuñán (2004b) p. 51.

114 "Es un error identificar el programa de desarrollo del embrión con su programa genético. El programa de desarrollo del embrión no está prefigurado, sino que se genera por interacciones moleculares y macromoleculares. En las etapas tempranas del desarrollo embrionario el programa de desarrollo se encuentra él mismo en desarrollo, se autogenera. Para la emergencia de este programa es tan esencial el código genético como su lectura, y esta depende del contexto, es decir, de elementos externos al ADN (de aquí el término "epigenético"). El contexto brinda las señalizaciones que son indispensables para gatillar respuestas celulares, y con ello el despliegue de los procesos de diferenciación celular”, Bascuñán (2004b) p. 52.

115 Alonso (2003) p. 42 y añade que el cigoto no es la misma realidad que el individuo generado al final del desarrollo, pues "no es el mismo y la misma cosa todo el tiempo de desarrollo", lo que ejemplifica con el supuesto de un cigoto genéticamente normal que se coloca en el endometrio de una madre homocigotótica para PAH (no sometida a tratamiento) y nace con microcefalia y otros trastornos severos, mientras que ese mismo cigoto generaría un individuo normal si se gestara en la misma madre sometida a una dieta de alimentación específica. En suma, según esta tesis el embrión no posee toda la información necesaria para dirigir el desarrollo ni aun en forma potencial, vid. su desarrollo en Alonso (2003) pp. 37-42; el mismo (2002) pp. 51-92; BolaDERAS (2007) pp. 101-107 y Gracia (2003), pp. 67-93.

116 Bascuñán (2004b) p. 50; Figueroa García-Huidobro (2007), p. 119. Tesis desarrollada, entre otros, por LACADENA (2003) pp. 113-123, quien además de cuestionar la individualización, hace lo propio con la "mismidad", esto es, la capacidad de reconocer lo propio como propio y lo no propio como extraño.

117 Bascuñan (2004b) p. 50. Joerden (2008) p. 14, agrega que si se acepta que la potencialidad del óvulo fecundado de llegar a ser persona fundamenta su derecho constitucional a la vida, tendría que aclararse desde un punto de vista jurídico por qué un óvulo no fecundado no es titular del derecho constitucional a la vida, atendido a que también a él podría atribuírsele, bajo determinadas circunstancias, la potencialidad de llegar a ser persona en el futuro. A lo anterior suele agregarse el clásico ejemplo del príncipe Carlos de Inglaterra, quien 
13. En la jurisprudencia constitucional comparada e internacional jamás un tribunal ha declarado que el nasciturus sea persona ${ }^{118}$.

14. La posición contraria se explicaría (solo) por la orientación religiosa que suscriben los autores que la sustentan ${ }^{119}$.

\section{b. Argumentos para AFirmar la Personalidad Del NO NACIDO Y SU DERECHO A}

\section{LA VIDA}

1. Con la fecundación se forma un nuevo ser, un embrión, que incluso en su carácter unicelular está definido genéticamente según lo que es y será en el futuro ${ }^{120}$. Se trata de un organismo vivo (contiene en sí mismo el principio de su desarrollo), completo (no como cualquier célula o tejido celular del cuerpo de un ser humano que son solo partes de un organismo) ${ }^{121}$, de la especie humana (es el resultado de la unión de gametos humanos), individual y distinto a la madre ${ }^{122}$. Es decir, es un ser humano, que a partir de su concepción comienza un ciclo vital y un proceso de desarrollo, organizado y con una finalidad interna, biológicamente caracterizado por su coordinación ${ }^{123}$, continuidad ${ }^{124}$ y gradualidad ${ }^{125}$. Es un proceso en que existen diversas fases, pero que no presenta quiebres ${ }^{126}$ ni momentos privilegiados $^{127}$.

actualmente no es rey y, aunque tiene la potencialidad de serlo, nadie le atribuiría ahora los derechos propios de un rey. Cfr. en la misma línea Figueroa García- Huidobro (2007) p. 120.

${ }^{118} \mathrm{Ni}$ siquiera el Tribunal Constitucional alemán, que lo reconoce como titular del derecho a la vida, pero no como persona, Figueroa García-Huidobro (2007), pp. 106 y 118.

119 Figueroa García-Huidobro (2007), p. 116. Indirectamente Bascuñán (2004b) p. 54, n. 8.

${ }^{120}$ En esta materia se consideran determinantes los conocimientos aportados por la biogenética y la medicina, demostrando que el embrión cuenta, desde la concepción, con un código genético completo, cfr. CorRAL (1989) p. 45; Fermandois (2004) p. 94-95; Nogueira (1997) p. 8; Ugarte (2004) p. 282-290 y Vivanco (2001) p. $468-471$.

${ }^{121}$ Cualquier célula humana, excepto el cigoto, es parte de un organismo humano; por su carga puede conocerse a qué cuerpo pertenece. En cambio el cigoto no se puede entender como parte de ningún organismo adulto. Cfr. Núñez de Castro (2008) p. 43.

${ }^{122}$ Tanto en el feto como en la madre se generan mecanismos de tolerancia, pues ambos distinguen al otro organismo como un extraño (por su diversidad genética); de lo contrario se produciría un rechazo inmunológico, Núñez de Castro (2008) pp. 81-84.

Aunque el embrión depende de la madre, es solo de modo extrínseco, que no se distingue sustancialmente de lo que ocurrirá con posterioridad al alumbramiento, Corral (1989) p. 46.

123 Existe una secuencia e interacción coordinada de actividad molecular y celular bajo el control del nuevo genoma, Bompiani et al. (2001).

${ }^{124}$ Que implica la unicidad del nuevo ser, pues es ininterrumpidamente el mismo e idéntico ser que se está formando, autónomamente, según un plan bien definido, aun pasando a través de estadios cualitativamente más complejos, vid. Bompiani et al. (2001) y Núñez de Castro (2008) p. 66 con referencias.

125 Existe una regulación, que debe ser intrínseca al embrión, que le permite alcanzar gradualmente su forma final, esto es, la estructura corporal de adulto.

${ }^{126}$ Carrasco (2004) p. 336; Nogueira (2007) p. 313. Quienes suponen un estatuto jurídico diverso según las etapas de desarrollo, se enfrenta al problema de "encontrar un punto en el proceso continuo que es la vida, en el que una de las modificaciones (puramente cuantitativas) que se producen en su transcurso pueda entenderse dotada de una significación cualitativa de entidad tal que justifique el tratamiento notablemente diferenciado que el ordenamiento jurídico le da al período que lo sucede respecto del que lo precede" Нorvitz y Soto PiÑeiro (2007) p. 80, n. 9. Sobre esto, también, Valenzuela (2003) pp. 165 y ss.

127 Incluso en el informe Warnock de 1984 (que por encargo del Parlamente británico y para regular la investigación con embriones humanos, fijó por consenso la edad de 14 días tras la concepción como edad límite para 
2. La individualidad del embrión no puede negarse ni siquiera por la posibilidad de gamelación, pues no existe oposición entre individualidad y divisibilidad ${ }^{128}$. Tampoco resulta negada por el desarrollo epigenético: ciertamente, la implementación del programa genético requiere la interacción con el medio, lo que confirma que todo ser vivo es un sistema abierto de continuo intercambio de materia, energía e información que va modulando la expresión del genoma fundamento de la corporeidad. Pero sigue siendo el genoma el que confiere la corporeidad y especificidad a ese nuevo organismo, sin que exista nueva información no contenida en él ${ }^{129}$. El paradigma epigenético no prueba ningún cambio sustantivo ${ }^{130}$.

3. La cualidad esencial de los derechos constitucionales radica en que emanan de la naturaleza humana ${ }^{131}$. En este sentido, el artículo $5^{\circ}$ inciso segundo CPR dispone que el ejercicio de la soberanía reconoce como limitación el respeto a los derechos esenciales que emanan de la naturaleza humana. Dado que el no nacido pertenece a la especie humana, resulta imperioso reconocerle, como esencial, su derecho a la vida ${ }^{132}$.

esas investigaciones) se afirma: "una vez que el proceso de desarrollo ha comenzado, no existe un estadio particular del mismo más importante que otro; todos forman un proceso continuo...”.

${ }^{128}$ No hay ninguna razón lógica para poner como condición necesaria de la individualidad la identidad numérica del embrión desde la fecundación hasta el nacimiento. Entre los distintos significados de la palabra, para estos efectos es individuo "cada ser organizado, sea animal o vegetal, respecto de la especie a que pertenece" ( $4^{\mathrm{a}}$ acepción RAE) y no lo "que no puede ser dividido" (2a acepción RAE). La posibilidad del cigoto, en sus primerísimos estadios de desarrollo, de fisionarse y dar lugar a gemelos no impide afirmar su individualidad: hasta antes de la fisión hay un individuo, después de la fisión hay dos. Pero en ningún momento deja de haber organismos individuales, tal como no se niega la individualidad de una lombriz, pese a que si se corta se obtienen dos lombrices. Cfr. Andorno (2004) p. 33; Carrasco (2004) p. 335; Núñez de Castro (2008) pp. 87, 105 y ss; Silva MacIver (1995) p. 184-185 y Ugarte (2004) pp. 297-298. Además, mayoritariamente se considera que la gemelación no se produciría por fisión (separación de una entidad en dos entidades, desapareciendo la entidad primaria), sino por gemación (formación de un brote o yema, permaneciendo la entidad primaria). Por tanto, existe un primer individuo que permanece, y un segundo que se origina a partir del primero. Esta tesis se ha confirmada experimentalmente en diferentes casos de discordancias genéticas en gemelos monocigóticos. Cfr. Núñez de Castro (2008) pp. 86-88.

En el supuesto, todavía más excepcional, de que se recombinen dos blastocistos para formar una quimera (fusión de embriones), existen dos individuos originalmente, pero uno incorpora las células del otro, que queda desintegrado.

${ }^{129}$ Existe un diálogo molecular entre la madre y el embrión, esencial para el desarrollo de este. Pero "ese diálogo no corresponde a una nueva información extragenética añadida al programa impreso en el genoma, sino a la implementación o desarrollo del programa mediante las señales autocrinas, paracrinas, endocrinas y ectocrinas, señales que no son genéticas, sino que median en el desarrollo epigenético”, Núñez de Castro (2008) p. 43, también pp. 59 y ss., y 78. La madre no aporta información en el sentido genético, pues el rol y la integración de la información materna son determinados por el mismo embrión. Sobre esto, Andorno (2004) p. 32 y NúNét de CAStro (2008) pp. 43, 59 y ss, 78. Esa relación entre el cigoto y la madre, con ser indispensable para el desarrollo del embrión, no lo constituye sino que presupone su existencia: no existe relación si no existe un ser que se relacione con el otro, Palazzini (2001) p. 118.

${ }^{130}$ La fecundación sigue siendo la "hora 0" en el proceso de gestación, Fermandois (2004) p. 114. El paradigma epigenético supone que el genoma es necesario pero no suficiente para el desarrollo del embrión, pero lo mismo ocurre en el adulto, cuyo genoma es condición necesaria para vivir pero no suficiente, NúÑEZ DE CASTRO (2008) p. 70.

${ }^{131}$ No como las proclamaciones de derechos previas al constitucionalismo en que los derechos se tenían solo en calidad de miembro de un determinado grupo social, cfr. Aldunate (2008) p. 47.

${ }^{132}$ Cfr. Silva MacIver (1995) pp. 187-192 y Soto Kloss (1991) pp. 141-142. 
4. Si lo determinante para la titularidad de los derechos constitucionales es el ser un humano, esa titularidad no puede quedar condicionada por su edad o etapa de desarrollo, pues entonces se estaría infringiendo el principio de igualdad ${ }^{133}$. Reconocido el dato biológico de que el nasciturus es un ser humano y que tiene vida "no existe una razón científica para establecer una diferencia cualitativa entre la vida humana intrauterina y la vida humana extrauterina" ${ }^{134}$. No se puede supeditar la condición humana a la adquisición de determinadas propiedades por el individuo, como la capacidad de sentir dolor, el desarrollo cerebral, la consciencia de sí mismo o el interés por sobrevivir; tesis que han llevado incluso a excluir del estatus de persona a algunos niños ya nacidos ${ }^{135}$. Por lo demás, "no se advierte bien por qué el 'tener' ha de prevalecer sobre el 'ser', cuando lo cierto es que solo quien 'es' persona puede desarrollar las 'propiedades' de la persona, en términos de una permanente apertura e indeterminación" 136 .

5. La equivalencia en el valor de la vida antes y después de nacer no significa la inconstitucionalidad de las disposiciones relativas al delito de aborto, pues existen divergencias, más allá del valor del bien jurídico, que justifican un tratamiento diferenciado ${ }^{137}$.

6. El artículo $1^{\circ}$ de la Constitución no condiciona la personalidad al nacimiento, sino que pone el acento en la libertad y dignidad de que gozan las personas al nacer ${ }^{138}$. Además, durante la discusión sobre la reforma al inciso $1^{\circ}$ de ese artículo ${ }^{139}$, en el Congreso Nacional, actuando como poder constituyente derivado, se acordó dejar constancia de que la modificación no cambiaba la noción sobre el término persona, que dentro de la tradición jurídica incluye como sujeto de derecho al que está por nacer ${ }^{140}$.

133 Distinguir entre el derecho a la vida del nasciturus y del nacido, siendo ambos individuos de la especie humana, importaría una diferencia arbitraria, Sото Kloss (1991) p. 141.

134 García (2010) p. 199. Recurrir a argumentos como la viabilidad o el mayor desarrollo de la vida humana independiente para asignarle un mayor valor llevaría a consecuencias inadmisibles, como la posibilidad de sacrificar a personas enfermas o ancianas para favorecer la vida de personas más jóvenes.

135 Sobre el desarrollo consecuente de estas tesis Silva Sánchez (2007) pp. 2 y ss., también Bianchi (1999) pp. 104-105.

136 Silva Sánchez (2007) p. 10. "El ser humano es un todo y no una propiedad o la suma de sus características, pues estas no definen, sino que suponen lo que el ser humano ya es. En efecto, si lo que constituye al ser humano no radica en lo que en sí mismo es, entonces depende de la arbitraria decisión que los demás le otorguen” ZuRriaráin (2005) p. 50, n. 24. En otras palabras, la presencia de ciertas funciones o de las condiciones para su exteriorización, presupone la existe de un sujeto que las hace posibles; ellas no son "el" sujeto, sino "del" sujeto, Palazzani (2001) p. 122.

137 Vid. supra VIII.

${ }^{138}$ Como cuando en la Declaración Universal de los Derechos Humanos de 1948 se afirma, en su art. 1º, que "todos los seres humanos nacen libres e iguales en dignidad y derechos", no significa que los no nacidos no sean seres humanos, sino que nadie nace esclavo ni deben existir distinciones entre los nacidos. Cfr. Corral (2005) p. 45.

${ }^{139}$ Cuando se cambió la expresión "hombres" por "personas", Ley de Reforma Constitucional No 19.611; Diario Oficial de 16 de junio de 1999.

${ }^{140}$ En el segundo trámite legislativo, durante la discusión en la Sala del Senado. Diario de Sesiones del Senado, sesión 21a 3 de marzo de 1999 . Acuerdo adoptado, precisamente, para dejar constancia en actas para la historia fidedigna del establecimiento de la norma constitucional, de modo que "el intérprete pueda citar con autoridad" en virtud de una interpretación auténtica del órgano legislativo. 
7. En la historia fidedigna del establecimiento del texto constitucional, si bien es notorio que se optó por rechazar una prohibición absoluta del aborto, no es menos cierto que la intención fue solo la de dar la posibilidad de flexibilizar esa prohibición. Sobre la base de que el no nacido tendría derecho a la vida -cuestión que se formuló explícitamente por varios ${ }^{141}$ y que ninguno objetó- la opción fue no pronunciar$\mathrm{se}^{142}$. Por lo demás, no se adoptó ningún acuerdo en la materia que permita hablar de la voluntad del constituyente, sino que las actas se limitan a dejar constancia de las opiniones divergentes de los comisionados ${ }^{143}$.

8. El art. 19 CPR tiene como objeto reconocer ciertos derechos a las personas, así deben interpretarse sus diversas menciones. En consecuencia, además, quienes figuran como beneficiarios de esos derechos no pueden tener otra calidad que la de personas $^{144}$.

9. El análisis sistemático sobre el uso del término persona en la Constitución lleva a concluir que este es empleado en diversos sentidos. En algunos casos se recurre a la tradicional distinción entre personas naturales y jurídicas (art. 19 No 12 y 19), en otros se refiere a la persona humana (art. $1^{\circ}$ inciso cuarto CPR), concepto al que, por razones lógicas, debe darse un alcance diferente que al de persona natural ${ }^{145}$, el que necesariamente deberá ser más extenso que aquel ${ }^{146}$. Entonces, el concepto de persona humana abarcaría a todos los individuos de la especie humana, aunque no gocen

${ }^{141}$ El Presidente de la Comisión, Sr. Ortúzar advierte que "al parecer, también hay acuerdo unánime para establecer el principio de que la ley protegerá el derecho a la vida del que está por nacer” (CENC, sesión 89, p. 16); en tanto que cuando se precisa que "no son los derechos en general los protegidos, sino la vida" (SiLVA BASCUÑán, CENC, sesión 90, p. 13) se hace para limitar el contenido de la protección, no para excluir que se trate del derecho a la vida. Por eso concluye que lo que se consagra en el art. 19 es el derecho a la vida del que está por nacer Fiamma Olivares (1980) pp. 234-241

En realidad, el punto sobre el que versó la discusión fue el de la posibilidad de que el aborto terapéutico y otros supuestos debían ser constitucionalmente prohibidos o no, y la solución fue la de no pronunciarse para dar margen a la decisión del legislador. La inclusión del inciso segundo del artículo 19 se explicaría por la necesidad de preocuparse del "único caso que puede plantear dudas" (Ovalle, CENC, sesión 90a, p. 19) y para permitir excepciones en la protección de ese derecho. Para precisar el contenido de los incisos $1^{\circ}$ y $2^{\circ}$ del art. 19, ORTúZAR resume "en el primer caso, se trata de consagrar en forma absoluta el derecho a la vida, y en el segundo, se desea dejar cierta elasticidad para que el legislador, en determinados casos, como, por ejemplo, el aborto terapéutico, no considere constitutivo de delito el hecho del aborto" (CENC, sesión 90, p. 16).

142 "Lo que no se quiso hacer en la Constitución fue ni hacer permisible el aborto terapéutico ni condenarlo (...) porque se le ha entregado al legislador la protección de la vida del que está por nacer”, OvalLE, CENC, sesión $90^{a}$, p. 15 . Aunque ni siquiera es uniforme la forma en que cada comisionado entendió ese "silencio" de la Constitución. Es la conclusión de Carrasco (1987) p. 54, previendo la manifestación de opiniones encontradas en lo futuro.

143 Cfr. Fermandois (2004) pp. 104-106 y Zapata (1998) p. 384.

144 Rodríguez (1992) p. 380.

145 "No se ve motivo alguno por el cual la Carta Fundamental quisiera reemplazar alguna formulación de dichos tradicionales conceptos [los de "persona natural” y "persona jurídica”] empleando una sinonimia completamente desconocida en la tradición jurídica occidental. Y si son conceptos diferentes han de referirse -necesariamente- a contenidos distintos", NúÑEz LeIva (2010) p. 80.

146 El Estado está al servicio de la persona humana dice el art. 10 inciso cuarto CPR; puesto que se trata de un precepto teleológico que define al beneficiario del principio de servicialidad del Estado, el concepto de persona humana al que alude no podría ser más restringido que el de persona natural, pues en tal caso el Estado estaría al servicio de solo un grupo de personas naturales. Por lo tanto, debe ser más extenso. Núñez LeIva (2010) p. 80. 
del carácter de personas naturales que asigna el Derecho civil. Existiendo diversos predicados de persona y puesto que el art. 19 no distingue -la Constitución asegura a todas las personas-, no debe el intérprete distinguir: comprende como titulares de los derechos allí consagrados a todas las personas, las que podrán serlo en la medida en que tengan aptitud para gozar del contenido del derecho de que se trate ${ }^{147}$.

10. En sede civil se estipula que la personalidad comienza con el nacimiento, pero se trata de la afirmación de la personalidad para otros fines: el reconocimiento de derechos patrimoniales o la responsabilidad. Es un concepto técnico ${ }^{148}$, aunque es criticado también en el ámbito de sus efectos propios ${ }^{149}$. En cambio, el reconocimiento de la personalidad para la protección debe partir de premisas diferentes, aquí debe poseer un significado más ontológico ${ }^{150}$ que convencional ${ }^{151}$ pues "en este ámbito, cualquier criterio que no sea el de la pertenencia a la especie humana nos convierte a unos en jueces de otros, lo que supone la propia negación del concepto de derechos humanos"152. Por lo demás, no puede pretenderse una interpretación de la Constitución "conforme a las leyes" 153 , ya que la función de aquella es, precisamente, la de inmunizar los derechos fundamentales frente a la ley ${ }^{154}$.

11. Esta interpretación no priva de contenido normológico al inciso $2^{\circ}$ del No 1 del art. $19 \mathrm{CPR}$, el que opera, en primer lugar, como una reserva de ley: la función de determinar y aplicar la norma constitucional corresponde exclusivamente al legislador ${ }^{155}$; y, en segundo término, como mandato de permanente protección, debido a la especial condición del no nacido y su incapacidad actual para requerir por sí mismo la protección de sus intereses ${ }^{156}$; en particular, implica la proscripción constitu-

147 Zapata (1988) p. 383; Núñez Leiva (2010) pp. 80-81. Similar Núñez Poblete (1998) p. 58.

148 Tanto así que en sede civil puede declararse la muerte presunta (y antiguamente también la muerte civil), la que no significa que desaparezca la necesidad de proteger a ese "ser" si sigue vivo en sentido natural.

${ }^{149}$ En cuanto el nasciturus es sujeto de algunos derechos, no es cosa, tiene una representante legal, puede estar sujeto a patria potestad o guarda, "pertenece indudablemente a la categoría de persona” Figueroa YÁÑEz (2001) pp. 150-151. También Corral (1990) passim.

$150 \mathrm{Sin}$ incurrir en una falacia naturalista, toda vez que la personalidad no se reconoce solo a partir de los datos de la ciencia; no es por el mero hecho de estar vivo que alguien tiene derecho a la vida, sino porque se trata de un ser humano. Si se asume que cualquier individuo de la especie humana ha de gozar del mismo reconocimiento que cualquier otro, no se puede negar ese reconocimiento al no nacido, Sánchez-Ostiz (2009) pp. 19 y 21. Así, los datos científicos no operan como fundamento sino como límite. La idea es que los conceptos tengan una correspondencia en la realidad, para no reducirlos a un mero juego intelectual, Zapata (1988) p. 378.

151 Sobre la evolución en el concepto de persona y la necesidad de aceptar un significado jurídico-institucional en relación con los derechos fundamentales, vid. Corral (2005) pp. 39-40.

152 Silva Sánchez (2007) p. 11, aludiendo a Spaemann.

153 Núñez Leiva (2010) p. 80 y Zapata (2008) p. 461.

${ }^{154}$ DÍAz (2006) p. 187.

155 Fermandois (2004) pp. 102-103 y Núñez Leiva (2010) p. 81. La previsión tiene sentido puesto que, aunque generalmente se estima que la reserva legal constituye un principio general en materia de regulación de los derechos constitucionales, nuestro sistema constitucional no contempla una reserva de tal alcance. Sobre esta cuestión y la evolución de la jurisprudencia constitucional al respecto, vid. Aldunate (2008) pp. 258-261.

156 Fermandois (2004) p. 102; Núñez Leiva (2010) pp. 81-82; Silva MacIver (1995) p. 195. Esta mayor protección no es discriminatoria toda vez que no existe una diferencia arbitraria, al igual que otros mandatos de protección, que no atentan contra el principio de igualdad en cuanto están justificados; por ejemplo, respecto de 
cional de una regulación que tolere el aborto sin necesidad de motivos en un periodo de la gestación (sistema de plazos).

12. Resulta absurdo interpretar una disposición que ordena una especial protección como una forma de sustraer a sus destinatarios de la categoría general a la que pertenecen perjudicando su estatus, al privarlos de la titularidad del derecho ${ }^{157}$.

13. El derecho a la vida y al reconocimiento de la personalidad están consagrados en una serie de instrumentos internacionales plenamente vigentes en nuestro país, y en relación con todo ser humano ${ }^{158}$.

14. El Tribunal Constitucional ha reconocido que la Constitución, en consonancia con las convenciones internacionales sobre Derechos Humanos, incluye al nasciturus cuando asegura el derecho a la vida, quien es persona desde el momento de la concepción ${ }^{159}$. También la Contraloría General de la República ha declarado que el no nato debe ser considerado como persona ${ }^{160}$.

15. La supuesta falacia retrospectiva que algunos denuncian se sostiene solo en atención a una particular forma de definir los términos de comparación; así, una semilla no es lo mismo que un árbol. Pero hay que añadir: no es lo mismo en sus aspectos accidentales, fenotípicos. Sin embargo, son una misma realidad; en la semilla está actualmente el mismo organismo del árbol. De igual modo, el embrión que tiene la potencialidad para adquirir las perfecciones humanas $-\mathrm{y}$, por tanto, la capacidad actual para adquirirlas-, es esencialmente idéntico al que ya las ha adquirido. Es el mismo sujeto, tal como un niño y un adulto. En consecuencia, no es que el cigoto sea un ser humano en potencia, sino que es un organismo humano en la primera fase de su ciclo vital ${ }^{161}$.

pueblos originarios, en derecho comparado, o en nuestra Carta Fundamental, en el art. 19 No 3 inciso tercero.

157 NúNét Leiva (2010) p. 82 y Zapata (2008) p. 462. Interpretada como mera protección de la vida -sin derecho a la vida- ella resulta incompleta e imperfecta, ZAPATA (1988) p. 382.

${ }^{158}$ En la Declaración Universal de los Derechos Humanos de 1948, art. 3º: "Todo individuo tiene derecho a la vida...", y art. 60 "Todo ser humano tiene derecho, en todas partes, al reconocimiento de su personalidad jurídica”, reiterado en el art. 16 del Pacto de Derechos civiles y políticos de 1966. La Declaración Americana de los Derechos y Deberes del Hombre, de 1948, art. I: "Todo ser humano tiene derecho a la vida, a la libertad y a la seguridad de su persona”. La Convención Americana sobre Derechos Humanos, de 1969, es enfática. Primero advierte, en su art. $1^{\circ}$ No 2, que "para los efectos de esta Convención, persona es todo ser humano", y luego reconoce que "toda persona tiene derecho al reconocimiento de su personalidad jurídica" (art. 30) y que "toda persona tiene derecho a que se respete su vida. Este derecho estará protegido por la ley y, en general, a partir del momento de la concepción" (art. 4 No 1). En la Convención sobre Derechos del Niño, de 1990, se entiende por niño "todo ser humano menor de dieciocho años" (art. 1º) y se le reconoce su derecho intrínseco a la vida (art. $\left.6^{\circ}\right)$. Estos antecedentes son esenciales para una interpretación armónica, sistemática y finalista del bloque constitucional, Nogueira (1997) p. 12.

159 Sentencia de 18 de abril de 2008, Rol No 740-2008, considerandos $54^{\circ}$ y $56^{\circ}$.

160 Dictamen No 25.403, de 21 de agosto de 1995, en relación con el art. 17 de la Ley No 19.123.

${ }^{161}$ En cualquier momento del ciclo vital se manifiesta actualmente todo el organismo en su fase correspondiente, cfr. Núñez de Castro (2008) p. 99-101, citando a Zubiri, Xavier (1996): Espacio. Tiempo. Materia (Madrid, Alianza) p. 666.: "En el ser vivo (...) ser sujeto significa estar por encima del cambio y las acciones, dominarlas internamente por orientación. El viviente no permanece a pesar del cambio, sino que cambia para poder seguir siendo el que es". 
16. La posición contraria se explicaría por una visión ideológica, en cuanto prescinde de los datos científicos, subordinando la verdad a la praxis ${ }^{162}$.

Como bien se advierte, nuestra Carta Fundamental no resuelve el tema de modo fehaciente, y existen diversos argumentos para las dos posiciones. La primera se construye, fundamentalmente, por una interpretación más literal y que atiende a la sistemática interna del art. 19 No 1; la segunda responde a criterios sistemáticos más amplios.

También es palmario que estamos frente a un problema de decisión normativa y no meramente biológico. Pero eso no significa que pueda negarse el dato biológico relativo a la calidad del nasciturus como individuo de la especie humana ${ }^{163}$. A ello se agrega que el Derecho se debería caracterizar por su sensibilidad por el débil, y que los verdaderos avances o logros sociales siempre han supuesto la incorporación a la vida social, al mundo de los derechos, de un número mayor de sujetos. Si el Derecho pretende garantizar las condiciones para la coexistencia humana, debe tender a la integración, no a la exclusión ${ }^{164}$.

En consecuencia, tanto por razones médicas, jurídicas y sociológicas, entendemos que el no nacido merece un reconocimiento equivalente al de cualquier otro individuo de la especie humana. Razones que también hacen que la referencia al momento del nacimiento como frontera decisiva y cambio radical de estatus jurídico resulte absolutamente insostenible ${ }^{165}$, pues las diferencias entre el nacido y el no nacido son muy pocas, y no se advierte justificación para hacer depender el derecho a la vida de ciertos aspectos externos casi irrelevantes.

En relación con este tema está en juego la noción misma de los derechos humanos. En las tan citadas palabras de Spaemann, "si debe haber en algún sentido algo así como derechos humanos, entonces solo puede haberlos en el supuesto de que nadie esté capacitado para juzgar si yo soy (un) sujeto de tales derechos. Pues la noción de derecho humano indica precisamente que el hombre no se convierte en miembro de la sociedad humana mediante una captación realizada sobre la base de determinadas características, sino en virtud de su propio derecho. En virtud del propio derecho solo puede significar: en virtud de

\footnotetext{
${ }^{162}$ Especialmente cuando se niega que el nasciturus tenga vida humana, SÁnchez-Ostiz (2009) p. 17.

163 Por lo demás, la mayoría de los argumentos de carácter biológico para negar el carácter de individuo de la especie humana al no nacido tienen sentido solo en las primera fases de su desarrollo. El mismo BASCUÑ́́N (2004b) pp. 50-51 establece que "desde un punto de vista biológico, la identidad individual del ser humano, en un sentido suficiente como para fundamentar ontológicamente su calificación como persona, solo puede afirmarse cuando se ha producido en ese organismo en desarrollo la expresión génica de aquellos rasgos que se consideran definitorios de la condición de un individuo de la especie humana, en el sentido específico con que los seres humanos nacidos lo son. Cuáles sean esos rasgos, esa es una cuestión controvertida. Como ejemplos tempranos en el desarrollo del embrión o feto puede indicarse la individualidad en tanto cancelación de la posibilidad de gemelación (día decimocuarto), el autorreconocimiento de la individualidad manifestado en el surgimiento del sistema inmunológico, o el término relativo de la constitución del programa de desarrollo embrionario (octava semana)". Aunque los plantea como ejemplos tempranos, y existen otros más tardíos (y más tempranos), es innegable que al poco tiempo de su desarrollo esas expresiones en el embrión no permiten obviar su identidad individual de ser humano.

164 Cfr. Sánchez-Ostiz (2009) p. 20 y Palazzani (2001) p. 128.

165 SÁnchez-Ostiz (2009) p. 19, n. 75 y Silva Sánchez. Si se quiere fijar un momento determinado al carácter inmemorial de la persona tiene que ser la fecundación, ya que los posibles momentos elegidos dependerían de esta y, además, su elección, sería arbitraria, cfr. Spaemann (1994) pp. 81-82.
} 
su pertenencia biológica a la species homo sapiens" ${ }^{166}$. Los derechos humanos suponen un minimum que es sustraído a la arbitrariedad del poder legislador. "Sin esa prepositividad no tendría ningún sentido hablar de derechos humanos, porque un derecho que puede ser anulado en cualquier momento por aquellos para los que ese derecho es fuente de obligaciones no merece en absoluto el nombre de derecho" 167.

Aunque no siempre se afirme explícitamente, el único camino para considerar propiamente justificados algunos supuestos de aborto es el de la definición del que está por nacer como no persona, y "en este sentido estricto es no persona para el Derecho penal aquel ser humano, y solo aquel ser humano, cuyo sustrato antropológico se deconstruye jurídica y/o filosóficamente, siendo reconstruido como un ente perteneciente al Derecho de cosas" 168 , posición que no resulta aceptable.

En definitiva, entendemos que el ser humano debe ser respetado y tratado como persona desde el momento de la concepción. Y este reconocimiento de su calidad de persona tiene efectos radicales en el juicio de ponderación propio del estado de necesidad.

\section{CONSECUENCIAS PARA LA PONDERACIÓN DE INTERESES EN EL ESTADO DE NECESIDAD}

Si el por nacer es un ser humano y, en consecuencia, debe ser reconocido como persona y tiene derecho a la vida, entonces es aplicable la máxima sobre la inviolabilidad de su vida, la que no puede ser objeto de balance o comparación con derechos o incluso con la vida de otro ser humano ${ }^{169}$. Rige aquí el principio general de que no cabe la ponderación de vida frente a vida, pues ante el Derecho toda vida humana tiene el mismo rango ${ }^{170}$ y no son admisibles cuantificaciones que solo conducirían a la inhumanidad ${ }^{171}$.

Ello no significa que la vida humana esté sin más sustraída a toda ponderación, pero implica que la eventual justificación de la muerte de otro nunca se podría apoyar en una diferente valoración de la vida humana en sí misma, sino de factores adicionales eventualmente concurrentes ${ }^{172}$. Ahora bien, como ya hemos advertido, eso solo podría ocurrir de

\footnotetext{
166 Spaemann, R. (1991), "La naturaleza como instancia moral de apelación”, en El hombre: inmanencia y trascendencia. Actas de las XXV Reuniones filosóficas, vol I, Pamplona, p. 66, cit. por Serna (1998) p. 46.

167 Spaemann (1998) p. 81. En el mismo sentido Silva Sánchez (2007) p. 10.

168 Silva Sánchez (2007) p. 4, definición que coincide dramáticamente con la de enemigo en sentido estricto, del tan denostado concepto de derecho penal del enemigo.

169 Barra (1996) p. 126.

${ }^{170}$ De modo general, y por la imposiblidad de jerarquizar vidas humanas excluyen la posibilidad del homicidio justificado por estado de necesidad Zaffaroni/Alagia/Zlokar (2003) p. 631. En contra de la opinión dominante, algunos proponen criterios diversos, como Soler (1978) pp. 367-369, quien asume un criterio subjetivizado para realizar la ponderación de males, criterio que ha sido abandonado en la actualidad. Por lo demás, su tesis es criticable porque "importa consagrar el más desenfrenado egoísmo, ya que su razonamiento conduce a justificar el sacrificio de una vida inocente sobre la sola base de la mayor fortaleza del sobreviviente; en esta forma se implanta como derecho la ley del más fuerte (...) se llegaría a la conclusión paradójica de que el más débil, aunque inocente, carecería del derecho de defenderse a la agresión injusta del más fuerte", CaBral, Compendio de Derecho penal. Parte general, p. 112, cit. por Lennon (1993) p. 64.

${ }^{171}$ Por todos Roxin (1997) p. 686.

${ }^{172}$ Roxin (1997) p. 690.
} 
modo muy excepcional, pues el criterio relativo al valor de los bienes jurídicos tiene un peso bastante decisivo al confrontar los intereses en conflicto, más todavía cuando se trata de bienes fundamentales y la conducta salvadora implica la segura destrucción de uno de ellos. En consecuencia, cuando lo que está en juego es una vida humana frente a otra, no se satisface el requisito propio del estado de necesidad justificante relativo al diverso valor de los intereses en conflicto ${ }^{173}$. Y en el evento en que el conflicto sea entre la vida del feto y otro bien jurídico distinto de la vida de la madre, resulta todavía más evidente que no puede invocarse un estado de necesidad justificante para lesionar lo primero ${ }^{174}$.

Menos plausible resulta la tesis de la justificación del aborto en virtud de un principio de exigibilidad diferenciada, invocado por BASCUÑÁN ${ }^{175}$, según el cual la exigibilidad del deber de tolerar el embarazo cesa en cualquier situación en la que el embarazo origine para la mujer el sacrificio de sus intereses por encima del margen y grado de afectación inherente a todo embarazo. Tras esta formulación sigue existiendo, como el mismo autor reconoce, un conflicto de intereses que se resuelve luego de un juicio de ponderación, dependiendo del peso específico que se le asigne a cada uno de esos intereses. Por eso, por ejemplo, considera "difícil admitir con base exclusiva en la Constitución la preponderancia de intereses patrimoniales de la mujer frente al interés constitucional en la preservación de la vida del feto" ${ }^{176}$. Otros supuestos de aborto por razones terapéuticas, ético-jurídicas o embriopáticas sí serían, a su juicio, justificados, pues primaría el interés de autonomía de la mujer como límite a la ponderación de intereses a favor de la vida del feto.

Ahora bien, resulta insuficiente plantear el problema como cuestión de inexigibilidad, especialmente si se pretende que se resuelva en términos de justificación. No puede centrarse la atención solo en un principio positivo o de beneficencia (dejar vivir o tolerar el embarazo) prescindiendo del principio negativo o de no maleficencia (no matar) que también concurre. Omitir lo segundo es desconocer una parte del problema, silenciando la propia realidad. "Por lo general, el aborto implica una agresión física al feto, no solo dejar de ayudarlo"177. La cuestión sería distinta, tal vez, si la mujer pudiera dejar de "tolerar" el embarazo -adelantar el parto, por ejemplo- sin infringir el deber de no dañar a otro, esto es, sin matar al niño por nacer. Pero entonces ya no estaríamos ante una conducta típica de aborto.

Además, toda esa construcción se sustenta sobre la base de negar que el feto tenga derecho a la vida, lo que incide radicalmente en el peso específico que se atribuye al interés en la conservación de su vida. Reemplazada esta premisa inicial, la conclusión a que se llega respecto del conflicto entre la vida del feto y los intereses patrimoniales de la mujer sería extensible a los demás conflictos, pues entonces primaría el derecho a la vida de niño por

\footnotetext{
${ }^{173}$ Excluimos la hipótesis de estado de necesidad defensivo por no ser aplicable respecto del nasciturus.

${ }^{174}$ Incluso partiendo de la base de que la vida del feto vale menos que la vida de la madre, LAUrEnzo (1990) pp. 235-242 concluye que estos supuestos no son de estado de necesidad justificante. Exceptúa únicamente el caso de peligro concreto para la vida de la madre, pero si el peligro se aleja entonces se incrementa el interés de protección de la vida en gestación (p. 239).

175 BASCUÑán (2004a) pp. 167 y ss.

176 BASCUÑÁN (2004a) p. 178.

177 DwORKIN (1994) p. 147.
} 
nacer o, en el caso de peligro para la vida de la madre, estaríamos frente a intereses equivalentes. En definitiva, no podría afirmarse que la conducta abortiva resulte justificada, al menos no en el sentido estricto de la expresión.

Por último, el deber de solidaridad exigido tampoco es tan extraordinario. Fuera de los casos muy excepcionales de peligro para la vida o la integridad física de la mujer, propios de la situación fáctica de su embarazo, la afectación de otros derechos, como la salud psíquica, el libre desarrollo de su personalidad, sus intereses patrimoniales, etc., pueden verse tanto o más amenazados cuando el niño ya ha nacido, pese a lo cual a los padres se les exige un deber de protegerlo y, por supuesto, no se les permite matarlo ${ }^{178}$.

En suma, si se reconoce un derecho a la vida al nasciturus no cabe aducir la existencia de una causa de justificación que legitime la decisión de la mujer y el médico de acabar con su vida. No porque se trate de un derecho absoluto y superior al de los ya nacidos, sino porque a su respecto no se pueden dar las situaciones que eventualmente podrían justificar la conducta de dar muerte a otro.

Si se insiste en interpretar los supuestos de aborto no punibles como causas de justificación, ello suele obedecer a razones prácticas. "La afirmación de la falta de antijuridicidad del aborto terapéutico no es consecuencia, por lo tanto, de un análisis estricto de las estructuras de descargo de la imputación comprometidas, sino de una decisión político-criminal que requiere introducir ciertas permisiones o limitaciones en relación con el aborto" 179 . Por ejemplo, para evitar los riesgos que suponen las prácticas abortivas clandestinas, para asegurar la disponibilidad de los médicos para la realización del aborto, para poder aplicar ayudas públicas ${ }^{180}$ e impedir la interferencia de terceras personas para defender la vida del nasciturus ${ }^{181}$.

Pero este criterio resulta criticable porque, "en primer lugar, hace un análisis completamente económico del aborto sin tener en cuenta que matar a un feto es, de por sí, una conducta injusta que no puede ser considerado un simple factor en un análisis global de mayor rentabilidad (...). Pero, lo que es peor, este planteamiento político-criminal parte de una premisa falsa, a saber: que una conducta ilícita se puede volver lícita para evitar que el autor del hecho salga lesionado por su propio accionar ilegal" ${ }^{182}$. La premisa no es válida, y menos cuando se trata de conductas tan graves, en que el resultado lesivo para la víctima del hecho es la destrucción de su vida. Por eso no se admiten como lícitas conductas delictivas menos graves, pero peligrosas para quienes las ejecutan -como el robo de cables de alta tensión- pese a que al permitirlas se podría conseguir que se realizaran de un modo menos peligroso -con la ayuda de electricistas e infraestructura adecuada- excluyendo todo tipo de riesgo para sus vidas ${ }^{183}$.

\footnotetext{
178 Cfr. Dworkin (1994) pp. 147 y 329.

179 García (2010) p. 200.

${ }^{180}$ Muchos lo reconocen expresamente, vgr. Massaglia (2005) p. 67.

${ }^{181}$ Critica la inclusión de criterios de oportunidad, Laurenzo (1990) pp. 226-230, 241.

${ }^{182}$ García (2010) pp. 200-201.

183 García (2010) p. 201. En el mismo sentido Núñez Poblete (1998) p. 72.
} 


\section{POSIBILIDAD DE EXCULPACIÓN. ALCANCE}

Excluir las posibilidades de justificación en el delito de aborto no significa que toda conducta abortiva sea, necesariamente, constitutiva de delito.

Ya hemos visto que la intervención que tiene una finalidad curativa y no esté directamente encaminada a provocar la muerte del feto, aunque la provoque, está comprendida dentro del riesgo permitido en el contexto de la actividad médica. Es, por lo tanto, objetivamente atípica respecto del delito de aborto.

Pero fuera de esos casos, en muchos otros también resultará excluido el delito en virtud de la situación de necesidad a la que responde, situación que va a operar como causa de exculpación, tanto para la propia mujer como para el médico o cualquier tercero que intervenga.

En realidad, la irresponsabilidad de la mujer en casos de riesgo para su vida o su salud nunca se ha puesto en duda, pues según la gravedad de la situación ella resulta amparada por la eximente de miedo insuperable del art. 10 No 9. Pero sí ha existido, hasta ahora, cierto debate sobre la posibilidad de exculpar a los terceros y, en particular, al médico que realiza el aborto, porque no sería él quien se encuentra en peligro por la presencia del feto. Aunque mayoritariamente se ha considerado que también queda exculpado ${ }^{184}$, algunos lo negaban, alegando que la exculpación es personalísima y no se comunica ${ }^{185}$. Por lo demás, esta ha sido la razón por la cual la jurisprudencia alemana invocara el estado de necesidad justificante supralegal para cubrir la situación del médico, o, en buena medida, la que ha impulsado la construcción de categorías intermedias que confieren relevancia en el plano de lo ilícito al estado de necesidad por colisión de bienes equivalentes, pese a que no exista una valoración positiva del comportamiento ${ }^{186}$.

Sin embargo, la posición que niega la inexigibilidad en la conducta de terceros se basa en una concepción de la exigibilidad que la reduce a situaciones de coacción psíquica como fenómeno ontológico ${ }^{187}$. Frente a esta visión, resulta más adecuado considerar que lo decisivo es el conflicto de motivos inherente a la situación de necesidad, el que debe valorarse objetivamente ${ }^{188}$. Desde esta perspectiva, en consecuencia, no es que se "comunique" la situación de inexigibilidad de la madre al médico, sino que este último se ve también enfrentado a un conflicto de motivos que puede hacer inexigible en su caso la conducta conforme a Derecho. Lo que hay que determinar es si el médico, enfrentado a una situación extrema de necesidad, es o no es motivable por las normas penales y, por ende, si es o no es culpable. Aunque él no sufra ninguna forma de miedo (que puede ser insuperable

${ }^{184}$ Admiten la posibilidad de exculpación respecto de la conducta del médico Politoff et al. (2006) p. 260; Politoff et al. (2011b) p. 98; Rodríguez (1992) p. 385 y Sanhueza (1990) p. 32. Lo considera difícil, EtCHEBERRY (1998) p. 109

185 Así Bascuñán (2004a) pp. 152 y 156, y UrRia (1993) pp. 72-74

${ }^{186}$ Entendiendo que estamos ante una causa de exclusión de la ilicitud penal, un ámbito libre de derecho, o adoptando una teoría unitaria frente al estado de necesidad. Vid. supra II

187 En este sentido se podría afirmar que en los casos de estado de necesidad exculpante la presión motivacional se presume, sin exigir la constatación individualizada de la ausencia de capacidad de motivación. Presunción que, finalmente, significaría excluir la pena con independencia de la culpabilidad del autor, así LaURENzo (1990) p. 319

${ }^{188}$ En este sentido SiLVa SÁnchez (1999) p. 175 
para la mujer embarazada según la gravedad de la situación), le es plenamente aplicable la situación de fuerza moral.

En cualquier caso, la incorporación de una eximente amplia de estado de necesidad en el art. 10 No 11 CP hace innecesaria mayor discusión sobre el punto, en cuanto ella aparece redactada en términos objetivos, sin considerar el efecto psicológico particular que la situación de necesidad genere en el autor del hecho. En consecuencia, es aplicable esta eximente y con carácter exculpatorio, al médico que practica el aborto por graves razones terapéuticas.

Eventualmente también puede haber otras situaciones de peligro para bienes jurídicos distintos de la vida de la madre, que también podrían resultar exculpados en virtud de esta disposición. Ahora bien, para ello deben reunirse todos los requisitos exigidos por la norma y, en particular, el relativo a la relación entre los males: que el mal causado no sea sustancialmente superior al que se evita. En este asunto cobra relevancia, nuevamente, tanto la discusión sobre el reconocimiento del niño por nacer como persona con derecho a la vida, como todas las características del juicio de ponderación de los intereses en conflicto, materia que desde la incorporación de este art. 10 No 11 supone un particular desafío para la doctrina penal en Chile.

\section{BIBLIOGRAFÍA CITADA}

Aldunate Lizana, Eduardo (2008): Derechos fundamentales (Santiago, LegalPublishing) $439 \mathrm{pp}$.

Alonso Bedate, Carlos (2002): "El estatuto ontológico del embrión humano: una visión alternativa", en: Beca Infante (ed.), El embrión humano (Santiago, Mediterráneo) pp. 51-92.

Alonso Bedate, Carlos (2003): "El estatuto ético del embrión humano: una reflexión ante propuestas alternativas", en: Alonso Bedate/Mayor Zaragoza (coords.), Gen-ética (Barcelona, Ariel) pp. 19-66.

Andorno, Roberto (2004): "La dimensión biológica de la personalidad humana: el debate sobre el estatuto del embrión”, Cuadernos de Bioética, Vol. 15, No 53: pp. 29-36. Disponible en http://www.aebioetica.org/rtf/03bioetica53.pdf [fecha de consulta: 3 de septiembre de 2011]

Baldó Lavilla, Francisco (1994): Estado de necesidad y legitima defensa (Barcelona, J. M. Bosch Editor) 387 pp.

Barra, Rodolfo Carlos (1996): La protección constitucional del derecho a la vida (Buenos Aires, Abeledo-Perrot) $182 \mathrm{pp}$.

Bascuñán Rodríguez, Antonio (2004a): "La licitud del aborto consentido en el derecho chileno", Derecho y Humanidades, Universidad de Chile, No 10: pp. 143-181.

Bascuñán Rodríguez, Antonio (2004b): "La píldora del día después ante la Jurisprudencia”, Estudios Públicos, No 95: pp. 43-89.

Bianchi, Ángel Alberto (1999): En contra del aborto (Buenos Aires, Ed. Abado de Rodolfo de Palma) 142 pp. 
Biompani, Adriano; Benedetti, Pierluigi; Vinicio, Ermelando; Dallapiccola, Bruno; Fazio, Vito; Mancuso, Salvatore; Moscarini, Massimo; Piccione, Emilio; Arduini, Domenico; Noia, Giuseppe; Benagiano, Giuseppe y Pirone, Giovanni (2002): L'Embrione come paziente (Dechiarazione dei Docenti delle 5 Facoltà di Medicina e Chirurgia, delle Università di Roma). Disponible en http://www.portaledibioetica.it/ documenti/000751/000751.htm [fecha de consulta: 2 de septiembre de 2011]

Boladeras, Margarita (2007): "Vida, vida humana, vida digna", Logos. Anales del Seminario de Metafísica, vol. 40: pp. 91-116. Disponible en http://www.bioeticanet.info/boladeras/VidaVHVDLogos.pdf [fecha de consulta: 22 de septiembre de 2011]

Bordalí Salamanca, Andrés/Zúñiga AÑazco, Yanira (2009): "Análisis del fallo del Tribunal Constitucional sobre la píldora del día después”, Anuario de Derechos Humanos, No 5: pp. 173-182.

Bramont-Arias Torres/García Cantizano (1998): Manual de Derecho penal. Parte especial (4a ed., Lima, San Marcos).

Bullemore G., Vivian y Mackinnon R., John (2007): Curso de Derecho penal. Parte especial (2a ed., Santiago, LexisNexis) tomo II, 304 pp.

Carbonell Mateu, Juan Carlos (1982): La justificación penal. Fundamento, naturaleza y fuentes (Madrid, Edersa) 205 pp.

Caro John, José Antonio (2010): "El aborto terapéutico y la relevancia del protocolo médico para la concreción del riesgo permitido”, en: El Mismo, Dogmática penal aplicada (Lima, Ara Editores) pp. 77-100.

Carrasco Delgado, Sergio (1987): "La garantía constitucional del derecho a la vida del que está por nacer”, XVIII Jornadas de Derecho Público, Universidad de Concepción: pp. 39-54.

Carrasco B., Alejandra (2004): “La píldora y la bioética en Chile”, Estudios Públicos N 96: pp. 325-344.

Castillo Alva, José Luis (2008): Derecho penal. Parte especial (Lima, Grijley) tomo I, 1127 pp.

Cea Egaña, José Luis (2004): Derecho constitucional chileno (Santiago, Ediciones Universidad Católica de Chile) tomo II, 733 pp.

CENC (1974): Comisión de Estudios de la Nueva Constitución de la República. Actas oficiales de la Comisión Constituyente, sesión 87a , celebrada el jueves 14 de noviembre; y sesión 90a , celebrada el 25 de noviembre.

Coca Vila, Ivó (2011): "Entre la responsabilidad y la solidaridad. El estado de necesidad defensivo", InDret. Revista para el análisis del Derecho, No 1, pp. 1-40. Disponible en: http://www.indret.com/pdf/789.pdf [fecha de consulta: 27 de julio de 2011]

Corral Talciani, Hernán (1989), "Comienzo de la existencia y personalidad del que está por nacer”, Revista de Derecho, PUCV, XIII: pp. 33-50.

Corral Talciani, Hernán (1990): "El concepto jurídico de persona. Una propuesta de reconstrucción unitaria”, Revista Chilena de Derecho, vol. 17, Tomo II: pp. 301-321.

Corral Talciani, Hernán (2005): "El concepto jurídico de persona y su relevancia para la protección del derecho a la vida", Ius et praxis, U. de Talca, Año 11, No 1: pp. 37-53. 
Cousiño MacIver, Luis (1979): Derecho penal chileno. Parte general (Santiago, Edit. Jurídica de Chile) tomo II, 602 pp. Creus, Carlos (1999): Derecho penal. Parte especial (6a ed., Buenos Aires, Astrea) tomo I.

Couso Salas, Jaime (2011) "Comentario al artículo 10 No 7", en Couso Salas / Hernández Basualto (dir.), Código penal comentado. Parte General. Doctrina y jurisprudencia (Santiago, Abeledo Perrot - LegalPublishing) pp. 234-239.

Cury Urzúa, Enrique (2005): Derecho penal. Parte general (8 ed., Santiago, Universidad Católica de Chile) 812 pp.

Díaz Pintos, Guillermo (2006): "La concepción totémica del nasciturus en la jurisprudencia del Tribunal Constitucional”, Persona y Derecho, Universidad de Navarra, No 54: pp. $185-212$.

Díez Ripollés, José Luis (2011): La categoría de la antijuridicidad en Derecho penal (2a ed., Montevideo- Buenos Aires, Bdef) 151 pp.

Diez Urzúa, Sergio (1999): Personas y valores. Su protección constitucional (Santiago, Edit. Jurídica de Chile) 411 pp.

Doyharcabal Casse, Solange (1994): "El derecho a la vida del nasciturus en la legislación chilena y comparada“, Revista Chilena de Derecho, PUC, Vol. 21, No 2: pp. 307-319.

Dworkin, Ronald (1994): El dominio de la vida: una discusión acerca del aborto, la eutanasia y la libertad individual (trad. Caracciolo/Ferreres, Barcelona, Ariel) 359 pp.

Eser, Albin (2010): en Schönke/Schröder, Strafgesetzbuch, Kommentar (28 a ed., München, Beck).

Etcheberry, Alfredo (1965): Derecho penal. Parte Especial (Santiago, Carlos E. Gibbs A., Editor).

Etcheberry, Alfredo (1976): Derecho penal. Parte Especial (2a ed. Santiago, Editora Nacional Gabriela Mistral).

Etcheberry, Alfredo (1998): Derecho penal. Parte Especial (3a ed., reimpr. 2010, Santiago, Editorial Jurídica de Chile) tomo III, 490 pp.

Evans de la Cuadra, Enrique (2004): Los Derechos Constitucionales (3a ed., Santiago, Edit. Jurídica de Chile), tomo I.

Evans Espiñeira, Eugenio (2000): Relación de la Constitución Política de 1980 (Santiago, ConoSur) 315 pp.

Fermandois Vöhringer, Arturo (2004): "La píldora del día después: aspectos normativos”, Estudios Públicos No 95: pp. 91-118.

Fernández Barros, Aurelio (1921): El aborto ante el Derecho penal i la Medicina legal (Santiago, Imprenta i Enc. "La Economía") 123 pp.

Fiamma Olivares, Gustavo (1980): "El Derecho a la Vida. Antecedentes en las Actas de la Comisión de Estudios Constitucionales", Revista de Derecho Público, No 27: pp. 223248.

Figueroa García-Huidobro, Rodolfo (2007): "Concepto de persona, titularidad del derecho a la vida y aborto", Revista de Derecho, Universidad Austral de Chile, Vol. XX, No 2: pp. 95-130.

Figueroa Yáñez, Gonzalo (2001): Derecho civil de la persona: del genoma al nacimiento (Santiago, Edit. Jurídica de Chile) 308 pp. 
FIsCHer, Thomas (2010): Strafgesetzbuch und Nebengesetze (57 ed., München, Beck) 2371 pp.

Fontán Balestra, Carlos (1995): Tratado de Derecho penal (Buenos Aires, Abeledo Perrot) tomo II.

Fuenzalida ZúNiga, Carmen Gloria (1998): "Protección jurídica del embrión en la legislación chilena”, Revista Chilena de Derecho, PUC, Vol. 25, No 4: pp. 827-850.

García Cavero, Percy (2008): Lecciones de Derecho penal. Parte General (Lima, Grijley) $823 \mathrm{pp}$.

García Cavero, Percy (2010): "El derecho a la vida del concebido en los casos de aborto terapéutico", Revista de Derechos Humanos, Universidad de Piura, No 1: pp. 193-206.

Garrido Montt, Mario (2007): Derecho penal. Parte Especial. Tomo III (3a ed., Santiago, Editorial Jurídica de Chile) 452 pp.

Gimbernat Ordeig, Enrique ([1974] 1990): "El estado de necesidad: un problema de antijuridicidad", ahora en: Gimbernat Ordeig, Estudios de Derecho penal (3a ed., Madrid, Tecnos) pp. 218-230.

Gimbernat Ordeig, Enrique (1984): "Prólogo" a Cuerda Riezu, Antonio, La colisión de deberes en Derecho penal (Madrid, Tecnos) pp. 13-28.

Gimbernat Ordeig, Enrique ([1974] 1990): "Por un aborto libre" ahora en: Gimbernat Ordeig, Estudios de Derecho penal (3a ed., Madrid, Tecnos) pp. 59-65.

Gómez Bernales, Gastón (2005): Derechos fundamentales y recurso de protección (Santiago, Ediciones Universidad Diego Portales) 665 pp.

Gracia, Diego (2003): "El estatuto de las células embrionarias", en: Alonso Bedate/MaYOR (coords.), Gen-ética (Barcelona, Ariel) pp. 67-93.

Gropp, Walter (2003): en Joecks/Miebach (edit.), Münchener Kommentar zum Strafgesetzbuch (München, Beck).

Günther, Hans-Ludwig (1995): "La clasificación de las causas de justificación en Derecho penal”, en: Luzón Peña y Mir Puig (coords.), Causas de justificación y de atipicidad en Derecho penal (Pamplona, Aranzadi) pp. 45-66.

Guzmán Brito, Alejandro (2001) El Derecho privado constitucional de Chile (Valparaíso, Ediciones Universitarias de Valparaíso) 302 pp.

Guzmán Dalbora, José Luis (2003): "La actividad libre de valoración jurídica y el sistema de justificación en el Derecho penal", Direito e Ciudadania, año V, no 16-17: pp. 17-32.

Hernández Basualto, Héctor (2011) “Comentario al artículo 10 No 11", en Couso SAlas / Hernández Basualto (dir.), Código penal comentado. Parte General. Doctrina y jurisprudencia (Santiago, Abeledo Perrot - LegalPublishing) pp. 267-275.

Hirsch, Hans Joachim (1992): "La regulación del estado de necesidad", en CGPJ, Jornadas sobre la 'Reforma del Derecho penal en Alemania', Madrid, 1992.

Hirsch, Hans Joachim (2008): "El estado de necesidad defensivo en la discusión alemana" (trad. E. Demetrio Crespo), en: García Valdés et al. (coord.), Estudios penales en homenaje a Enrique Gimbernat (Madrid, Edisofer) pp. 1005-1031.

Horvitz Lennon, María Inés y Soto Piñeiro, Miguel (2007): “Consideraciones críticas sobre la regulación del delito de aborto en el anteproyecto de nuevo código penal elabo- 
rado por el foro del Ministerio de Justicia”, Revista de Estudios de la Justicia, No 9: pp. $75-120$.

Jakoвs, Günther (1997): Derecho penal. Parte General. Fundamentos y teoría de la imputación (trad. Cuello Contreras - Serrano González de Murillo, 2a ed., Madrid, Marcial Pons) $1113 \mathrm{pp}$.

Jаковs, Günther (1998): La imputación objetiva en Derecho penal (trad. Cancio Meliá, Lima, Grijley) II9 pp.

Jаковs, Günther (2000): “¿Existe un aborto lícito de personas?” (trad. González Rivero), Revista del Poder Judicial 60: pp. 159-168

Jiménez de Asúa, Luis (1965): Tratado de Derecho penal (3a ed., Buenos Aires, Losada), tomo III, $1102 \mathrm{pp}$.

Joerden, Jan C. (2008): "Beginn und Ende des Lebensrechtsschutzes", Zeitschrift für die Gesamte Strafrechtswissenschaft, vol. 120: pp. 11-21.

Juanatey Dorado, Carmen (2010) en Boix Reig (dir.), Derecho penal. Parte especial (Madrid, Iustel) vol. I, 534 pp.

Kindhäuser, Urs (2009): Strafrecht Besonderer Teil I. Straftaten gegen Persönlichkeitsrechte ( $4^{\mathrm{a}}$ ed., Baden-Baden, Nomos) 468 pp.

Künsemüller Loebenfelder, Carlos (1986): "Responsabilidad penal del acto médico", Revista Chilena de Derecho, PUC, Vol. 13, No 2: pp. 259-269.

Labatut Glena, Gustavo (2007): Derecho penal (7a ed., reimpresión, Santiago, Editorial Jurídica de Chile) tomo II, 263 pp.

Lacadena, Juan Ramón (2003): "Individualización y mismidad genética en el desarrollo humano", en: Alonso Bedate (coord.), Gen-ética (Barcelona, Ariel) pp. 113-123.

Laje Anaya, Justo (2003): El homicidio y el aborto en la doctrina judicial argentina (Córdoba, Alveroni) 388 pp.

Laurenzo Copello, Patricia (1990): El aborto no punible: el art. 417 bis del Código Penal (Barcelona, Bosch: S.P.I.C.U.M.) 356 pp.

Lennon, Lucas J. (1993): “La protección penal de la persona por nacer", en Alvarado Uriburu et al., El derecho a nacer (Buenos Aires, Abeledo Perrot).

Luzón Peña, Diego Manuel (1989): "Indicaciones y causas de justificación en el aborto", en Criminología y Derecho penal al servicio de la persona. Libro Homenaje al Profesor A. Beristain (San Sebastián, Edit. Instituto Vasco de Criminología) pp. 779-796.

Luzón PeÑa, Diego Manuel (2006): Aspectos esenciales de la legítima defensa (2a ed., reimpr., Montevideo-Buenos Aires, BdeF) 688 pp.

Lyon Puelma, Alberto (2007): Persona naturales (3a. ed., Santiago, Universidad Católica de Chile) 215 pp.

Manríquez Bustos, Edmundo (1963): Protección penal de la vida humana en su primera etapa (Santiago, Edit. Jurídica de Chile) 84 pp.

Martínez Cantón, Silvia (2006): La ponderación en el estado de necesidad (León, Universidad de León) 979 pp.

Martínez Cantón, Silvia (2010): "Nuevas consideraciones sobre el derribo de aviones con pasajeros desde la perspectiva del estado de necesidad”, en: Luzón Peña, Diego 
Manuel (dir.), Derecho penal del Estado Social y Democrático de Derecho. Libro homenaje a Santiago Mir Puig (Madrid, La Ley) pp. 405-444.

Massaglia de Bacigalupo, María Valeria (2005): Aborto: embarazos incompatibles con la vida: anencefalia y adelantamiento del parto: ¿delito, mala praxis o cumplimiento del deber profesional? (Buenos Aires, Lajouane) $351 \mathrm{pp}$.

Mayer Lux, Laura (2011): "La vida del que está por nacer como objeto de protección penal”, Revista de Derechos Fundamentales, Universidad Viña del Mar, No 5: pp. 63-80.

Mir Puig, Santiago (2005): Derecho penal. Parte general (7a ed., 2a reimpr., MontevideoBuenos Aires, Bdef) 781 pp.

Mohor Abuauad, Salvador (1988): "Consideraciones jurídicas y metajurídicas en torno a una eventual despenalización del aborto en Chile a la luz de la nueva Constitución”, Revista de Legislación y Documentación en Derecho, BCN, Año X, No 1: pp. 17-82.

Molina Fernández, Fernando (2008): "Naturaleza del sistema de justificación en Derecho penal”, en: Carbonell Mateu (dir.), La justificación penal: balance y perspectivas (Valencia, Tirant lo Blanch) pp. 13-35.

Molina Guaita, Hernán (2011): Derecho constitucional (11 a ed., Santiago, Abeledo Perrot) $596 \mathrm{pp}$.

Muñoz Conde, Francisco (2009): Derecho penal. Parte especial (17 a ed., Valencia, Tirant lo Blanch) $1004 \mathrm{pp}$.

Muñoz Conde, Francisco y García Arán, Mercedes (2007): Derecho penal. Parte general (7a ed., Valencia, Tirant lo Blanch) 622 pp.

Nogueira Alcalá, Humberto (1997): "El derecho a la vida en el ordenamiento jurídico chileno", Gaceta Jurídica, No 207, pp. 7-29.

Nogueira Alcalá, Humberto (2007): Derechos fundamentales y garantías constitucionales (Santiago, Librotecnia) tomo I, pp.

Núñez de Castro, Ignacio (2008): De la dignidad del embrión. Reflexiones en torno a la vida humana naciente (Madrid, Universidad Pontificia Comillas) 178 pp.

Núñez LeIva, José Ignacio (2010): “Estatuto constitucional del embrión humano”, Hemiciclo. Revista de Estudios Parlamentarios, Academia Parlamentaria de la Cámara de Diputados, No 2, Primer semestre de 2010, pp. 67-86.

Núñez Poblete, Manuel Antonio (1998): "El derecho a la vida o el deber de respetar la vida”, en: García-Huidobro Correa/Martínez Estay/Núñez Poblete, Lecciones de Derechos Humanos (Valparaíso, Edeval), pp. 45-94.

Ossandón Widow, M. Magdalena (2011): "La intención de dar muerte al feto y su relevancia para la imputación objetiva y subjetiva en el delito de aborto", Revista de Derecho, Universidad Católica del Norte, año 18 No 2: pp. 103-136.

Oxman Vilches, Nicolás (2004): "Las figuras penales del delito de aborto", Revista de Derecho, Universidad Central, año 10, No 6: pp. 231-254.

Palazzani, Laura (2001): "Lo staturo giuridico dell'embrione umano", Persona y derecho, Universidad de Navarra, No 44: pp. 113-131

Parada Guzmán, César (1963), El aborto en nuestra legislación y jurisprudencia (Santiago, Edit. Jurídica de Chile) 102 pp. 
Perron, Walter (1995), "Principios estructurales de la justificación en los derechos penales español y alemán”, en: Luzón Peña y Mir Puig (coords.), Causas de justificación y de atipicidad en Derecho penal (Pamplona, Aranzadi) pp. 67-86.

Perron, Walter (1998): “Justificación y exclusión de la culpabilidad a la luz del Derecho comparado (con especial consideración del Derecho Penal español), Anuario de Derecho penal y ciencias penales, Tomo XLI, Fascículo I: pp. 137-156.

Politoff, Sergio; Grisolía, Francisco y Bustos, Juan (2006): Derecho Penal Chileno. Parte Especial (2a ed., Santiago, Editorial Jurídica Congreso) 435 pp.

Politoff, Sergio; Matus, Jean Pierre y Ramírez, Cecilia (2011a): Lecciones de Derecho Penal chileno. Parte General (2a ed., reimpresión, Santiago, Editorial Jurídica de Chile) 613 pp.

Politoff, Sergio; Matus, Jean Pierre y Ramírez, Cecilia (2011b): Lecciones de Derecho Penal chileno. Parte Especial ( $2^{a}$ ed., reimpresión, Santiago, Editorial Jurídica de Chile) 689 pp.

Precht Pizarro, Jorge (1992): “Consideraciones ético-jurídicas sobre el aborto terapéutico", Revista Chilena de Derecho, Vol. 19, No 3: pp. 509-525.

Rivacoba y Rivacoba, Manuel de (1995): Las causas de justificación (Buenos Aires, Hammurabi) $336 \mathrm{pp}$.

Robles Planas, Ricardo (2010): “En los límites de la justificación. La colisión de intereses vitales en el ejemplo del derribo de aviones y de otros casos trágicos”, en: Luzón Peña, Diego Manuel (dir.), Derecho penal del Estado Social y Democrático de Derecho. Libro homenaje a Santiago Mir Puig (Madrid, La Ley) pp. 445-473.

Rodríguez Collao, Luis (1992): “El delito de aborto frente a la Constitución de 1980", Revista de Derecho, PUCV, XIV: pp. 369-387.

Rodríguez Collao, Luis (2010): Apuntes de Derecho penal I, inédito.

Roxin, Claus (1997): Derecho penal. Parte general (trad. de la 2a ed. alemana por Luzón Peña; Díaz y García Conlledo y De Vicente Remesal, Madrid, Civitas) tomo I, 1071 pp.

Roxin, Claus (2007): "Las causas de justificación y de exculpación y su delimitación de otras causas de exclusión de la pena", ahora en Roxin, Claus, La teoría del delito en la discusión actual (trad. M. Abanto Vásquez, Lima, Grijley) pp. 225-258.

Rozas Vial, Fernando (1989): "Problemas jurídicos y morales que plantean la inseminación artificial y la fecundación in vitro", Revista Chilena de Derecho, Vol. 16, No 3: p. 725-752.

SÁnchez-Ostiz Gutiérrez, Pablo (2009): “'Tienen todos derecho a la vida? Bases para un concepto constitucional de persona”, Revista electrónica de ciencia penal y criminología, No 11, 11: pp. 1-23. Disponible en http://criminet.ugr.es/recpc/11/recpc11-11.pdf [fecha de consulta: 31 de agosto de 2011]

Sanhueza Romero, Juana (1990): “Tratamiento jurídico del aborto terapéutico”, Revista de Derecho, Universidad de Concepción, N 187: pp. 27-33.

Santibáñez Torres, M. Elena y Vargas Pinto, Tatiana (2011): "Reflexiones en torno a las modificaciones para sancionar el femicidio y otras reformas relacionadas (Ley No 20.480)", Revista Chilena de Derecho, vol. 38, No 1: pp. 193-207. 
Sanz Morán, Ángel José (2000): “Teoría general de la justificación”, Doctrina penal, No 5: pp. 74-89.

SATZGer, Helmut (2008): Der Schwangerschaftsabbruch [SS 218 ff. StGB] (Jura).

Serna, Pedro (1998): "El derecho a la vida en el horizonte cultural europeo de fin de siglo”, en: Massini/ Serna (eds.), El derecho a la vida (Pamplona, Eunsa) pp. 23-79.

Silva MacIver, Jaime (1995): "El nasciturus y el derecho a la vida", Revista de derecho público, U. Chile, No 57/58: pp. 177-198.

Silva Sánchez, Jesús María (1999): “Sobre las actuaciones en una 'situación de necesidad' que no implican deberes de tolerancia”, en Luzón Peña y Mir Puig (dir.), Cuestiones actuales de la teoría del delito (Madrid, McGraw-Hill) pp. 155-184.

Silva Sánchez, Jesús María (2003): El delito de omisión. Concepto y sistema (2a ed., Montevideo-Buenos Aires, Bdef) 502 pp.

Silva Sánchez, Jesús María (2007): "Los indeseados como enemigos: la exclusión de seres humanos del status personae", Revista electrónica de Ciencia penal y Criminología, No 9: pp. 1-18. Disponible en http://criminet.ugr.es/recpc/09/recpc09-01.pdf [fecha de consulta: 30 de agosto de 2011]

Singer, Peter (2003): Desacralizar la vida humana. Ensayos sobre ética (Madrid, Cátedra) 494 pp.

Soler, Sebastián (1978): Derecho penal argentino (3a ed., Buenos Aires, Tea), tomo I, 386 pp.

Soто Kloss, Eduardo (1991): "La noción de persona en la Constitución: a propósito del que está por nacer”, Revista de Derecho público, U. Chile, No 50, 1991, pp. 137-144.

Spaemann, Robert (1994): "La inviolabilidad de la vida humana", Anuario Filosófico, 27: pp. 69-87.

Terragani, Marco Antonio (2000): Delitos contra las personas (Mendoza, Ediciones Jurídicas de Cuyo) 601 pp.

Thomson, Judith Jarvis (1983): "Una defensa del aborto", en Finnis, John et al.: Debate sobre el aborto. Cinco ensayos de filosofía moral (Madrid, Cátedra) p. 9-32.

UGarte Godoy, José Joaquín (2004): "Momento en que el embrión es persona humana", Estudios Públicos, No 96: pp. 281-323.

Ugarte Godoy, José Joaquín (2006): "El derecho a la vida y la Constitución", Revista Chilena de Derecho, PUC, Vol. 33, No 3: pp. 509-527.

Urria Hering, Pablo (1993): Fundamentación médico legal del aborto terapéutico, Memoria, Universidad Católica de Valparaíso (inédita).

Valenzuela Saldías, Jonatan (2003): "Algunas consideraciones sobre el estatuto del embrión preimplantacional en Chile", Revista de Estudios de la Justicia, No 3: pp. 165-177.

Van Weezel de la Cruz, Alex (2009): "Contrapunto: El aborto terapéutico", Revista Chilena de Derecho, PUC, Vol. 36, No 1: pp. 205-208.

VArela del Solar, Jorge Luis (1990): “Derechos humanos y aborto”, Revista de derecho público, U. Chile, No 47/48: pp. 195-218.

Verdugo/Pfeffer/Nogueira (1994): Derecho constitucional (2a ed., Santiago, Edit. Jurídica de Chile) tomo I. 
Vivanco, L./Martínez, A./Jouve, N. (2010): "Valoración bioética y biojurídica del diagnóstico genético preimplantatorio en España”, Cuadernos de bioética, XXI, No 2: pp. 213-230.

Vivanco Martínez, Ángela (2001): "El derecho a la vida y la discusión acerca del concepto de persona humana en el ámbito constitucional", Revista Chilena de Derecho, PUC, Vol. 28, No 2: pp. 467-480.

Vivanco Martínez, Ángela (2002): "Aspectos jurídicos del llamado aborto terapéutico en Chile”, Ars médica. Revista de Estudios Médico Humanísticos, PUC, Vol. 6, No 6. Disponible en: http://escuela.med.puc.cl/publ/arsmedica/ArsMedica6/Art13html [fecha de consulta 28 de julio de 2011].

Zapata Larraín, Patricio (1988): "Persona y embrión humano. Nuevos problemas legales y su solución en el derecho chileno", Revista Chilena de Derecho, PUC, Vol. 15, No 2-3: pp. 375-391.

Zapata Larraín, Patricio (2008): "Comentario a la sentencia del Tribunal Constitucional Rol 740-07”, Revista de Derecho Público, U. de Chile, No 70: pp.

Zurriaráin, Roberto Germán (2005), "El concepto de vida 'prepersonal' en el Futuro de la naturaleza humana de J. Habermas”, Cuadernos de Bioética, No 56: pp. 43-50. Disponible en: http://www.aebioetica.org/archivos/03-BIOETICA-56.pdf [fecha de consulta 8 de septiembre de 2011].

\section{NORMAS CITADAS}

Código de Ética, Colegio Médico de Chile, A.G., 2008.

Código Sanitario, Decreto con fuerza de ley 725, Diario Oficial 31 de enero de 1968.

Ley No 18.826, Sustituye artículo 119 del Código Sanitario. Diario Oficial 15 de septiembre de 1989.

Ley No 20.120, Sobre la investigación científica en el ser humano, su genoma, y prohíbe la clonación humana. Diario Oficial 22 de septiembre de 2006.

Ley No 20.480, Modifica el Código Penal y la Ley No 20.066 sobre violencia intrafamilar, estableciendo el "femicidio", aumentado las penas aplicables a este delito y reforma las normas sobre parricidio. Diario Oficial 18 de diciembre de 2010. 